\title{
Differential responses of phytoplankton and heterotrophic bacteria to organic and inorganic nutrient additions in coastal waters off the NW Iberian Peninsula
}

\author{
Sandra Martínez-García ${ }^{1, *}$, Emilio Fernández ${ }^{1}$, Xosé-Antón Álvarez-Salgado ${ }^{2}$, \\ Jose González ${ }^{1}$, Christian Lønborg ${ }^{2,3}$, Emilio Marañón ${ }^{1}$, Xosé-Anxelu G. Morán ${ }^{4}$, \\ Eva Teira ${ }^{1}$ \\ ${ }^{1}$ Departamento Ecoloxía e Bioloxía Animal, Universidade de Vigo, Campus Lagoas-Marcosende, 36310 Vigo, Spain \\ ${ }^{2}$ CSIC, Insituto de Investigacións Mariñas, Eduardo Cabello 6, 36208 Vigo, Spain \\ ${ }^{3}$ Scottish Association for Marine Science, Oban, Argyll PA37 1QA, UK \\ ${ }^{4}$ Instituto Español de Oceanografía, Centro Oceanográfico de Xixón, Camín de L'Arbeyal s/n, 33212 Xixón, Spain
}

\begin{abstract}
The short-term effects of inorganic $\mathrm{N}$ and $\mathrm{P}$ (nitrate, ammonium, phosphate) and organic $\mathrm{C}$ and $\mathrm{N}$ (glucose, amino acids) input, added separately as well as jointly, on microplankton community structure and metabolism were studied in 6 microcosm experiments conducted from February to July 2008 in a eutrophic coastal embayment in NW Spain under contrasting hydrographic conditions. The responses of planktonic communities were highly variable. Strong positive effects of combined inorganic and organic nutrient enrichments for phytoplankton and heterotrophic bacteria were found. In most experiments enhanced phytoplankton biomass and productivity (primary production increased up to 5.5-fold) was measured after mixed (inorganic plus organic) additions but phytoplankton responded only in one of the experiments after inorganic additions. Heterotrophic bacteria responded faster than phytoplankton to the additions but were never affected by inorganic nutrient additions, suggesting a $\mathrm{C}$ limitation of bacterial activity in this coastal environment. Heterotrophic bacteria biomass, productivity, and respiration responded to mixed additions (containing $\mathrm{C}, \mathrm{N}$, and $\mathrm{P}$ ) in all the experiments (bacterial production increased from 14- to 34-fold) whereas its response to organic (containing $\mathrm{C}$ and $\mathrm{N}$ ) additions greatly differed among experiments (bacterial production increased from 0.6 - to 21 -fold), which could be partially related to $\mathrm{P}$ availability. A general increase in bacterial growth efficiency occurred only after mixed additions (up to 2-fold). The tendency towards heterotrophy of the microbial plankton community was weaker after the mixed (Production/Respiration (P/R) ratio changes from 0.34 - to 1.6-fold) than after the organic additions (P/R changes from 0.16 to 0.8 -fold). Our results suggest that phytoplankton requirememnts for organic nutrients for growth and $\mathrm{P}$ deficiency of bacterial populations intermittently occur in this coastal area.
\end{abstract}

KEY WORDS: Nutrient additions · Organic nitrogen · Phytoplankton · Bacteria

Resale or republication not permitted without written consent of the publishe

\section{INTRODUCTION}

Anthropogenic alterations of global biogeochemical cycles are changing the magnitude and nature of matter inputs into the ocean (Falkowski et al. 1998, Galloway \& Cowling 2002, Matthews 2006, Duce et al. 2008). This phenomenon is particularly relevant in coastal regions, where a large fraction of the human population is concentrated (Vitousek et al. 1997, Paerl et al. 2002).

A broad range of studies in coastal waters have shown that nitrogen $(\mathrm{N})$ controls the rate of primary production (PP) in many estuarine and coastal waters (Nixon \& Pilson 1983, Oviatt et al. 1995). It is estimated that $\mathrm{N}$ inputs into the ocean have increased 2- to 3-fold in the past century (up to 15 -fold in some coastal loca- 
tions; Howarth \& Marino 2006) and are expected to steadily increase over the next few decades (Galloway et al. 2004). Consistently, a tendency towards eutrophication in many coastal systems due to the increasing inputs of nutrients has been widely reported (Nixon 1995, Cloern 2001, Gruber \& Galloway 2008).

A significant fraction, 40 to $50 \%$, of the $\mathrm{N}$ and carbon (C) entering the marine system from riverine discharge is known to be organic (Meybeck 1993). Atmospheric water-soluble organic $\mathrm{N}$ entering the ocean accounts for 20 to $70 \%$ of the total amount of $\mathrm{N}$ deposited annually, and 45 to $75 \%$ of the dissolved organic $\mathrm{N}$ (DON) in atmospheric deposition is biologically available (Peierls \& Paerl 1997, Seitzinger \& Sanders 1999).

Although organic N might constitute a relevant fraction of the total $\mathrm{N}$ inputs into coastal regions, the effects of inorganic and/or organic $\mathrm{N}$ inputs on both phytoplankton and heterotrophic bacteria remain poorly studied (Thingstad et al. 1999, Davidson et al. 2007). To the best of our knowledge, only the study by Davidson et al. (2007) has concurrently addressed the differential effect of inorganic versus organic $\mathrm{N}$ inputs on both phytoplankton and bacteria during one mesocosm experiment conducted with coastal waters. Both inorganic and organic $\mathrm{N}$ are known to be utilized by heterotrophic bacteria and phytoplankton (Antia et al. 1991, Kirchman 1994, Joint et al. 2002, Bronk et al. 2007) and different degrees of competition and limitation may be occurring in coastal zones as the magnitude and nature of nutrient inputs vary. Furthermore, remineralization and excretion processes within the microbial compartment may supply different inorganic and/or organic nutrients to phytoplankton and bacteria, so coupling between autotrophic and heterotrophic microorganisms may be also playing an important role (Azam et al. 1983, Croft et al. 2005). Therefore, the distinct nutrient requirements and uptake efficiencies of bacteria and phytoplankton, as well as the competition and/or coupling processes between them, may determine the responses of the microbial communities to nutrient inputs.

The aim of the present study was to assess the shortterm response of the NW Atlantic coastal microbial planktonic communities to inorganic and/or organic nutrient additions during contrasting oceanographic conditions. Differential responses of phytoplankton and heterotrophic bacteria to distinct nutrient inputs are expected depending on both the initial environmental conditions and microbial community structure and the interaction between both microbial compartments, which, in turn, will determine the impact of nutrient loading on the $\mathrm{C}$ fluxes through the microbial plankton community. We hypothesized that phytoplankton will mainly benefit from inorganic nutrient inputs, while heterotrophic bacteria will fundamen- tally profit from both organic and mixed nutrient inputs, leading the system towards net heterotrophy. To test this hypothesis, we evaluated the shortterm response of both phytoplankton and heterotrophic bacteria to inorganic versus organic or mixed nutrient additions under 6 contrasted environmental conditions.

\section{MATERIALS AND METHODS}

Survey area. The coastal system of the NW Iberian Peninsula is characterized by the intermittent upwelling of cold and inorganic nutrient-rich Eastern North Atlantic Central Water (Nogueira et al. 1997). Although upwelling-favorable northerly winds prevail from March to September and downwelling-favorable southerly winds the rest of the year, out-of-season upwelling or downwelling events have been frequently recorded (Álvarez-Salgado et al. 2002, 2006). The Ría de Vigo is a eutrophic embayment located in this coastal area. Water exchange between the embayment and the adjacent shelf is determined by the balance between river discharge and shelf wind stress, promoting upwelling or downwelling.

It has been estimated that for our study area, ca. 10\% of the inorganic $\mathrm{N}$ supply during the upwelling period comes from a continental source (Álvarez-Salgado et al. 1996). This percentage is larger during downwelling periods, coinciding with higher precipitation and river flows, which additionally introduce significant amounts of organic N (Álvarez-Salgado et al. 1996, 2002). Several studies have reported atmospheric deposition of $\mathrm{N}$ in this area (Vázquez et al. 2003, Rodriguez \& Macías 2006). Wet atmospheric deposition has been calculated to introduce 10 to $25 \mathrm{~kg} \mathrm{~N} \mathrm{ha}^{-1}$ $\mathrm{yr}^{-1}$ in the Ría de Vigo (Rodriguez \& Macías 2006).

The Ría de Vigo and its adjacent shelf is therefore a highly productive and very dynamic coastal system, where different microbial communities can be found over short time and space scales (Cermeño et al. 2006).

Experimental design. Two different locations, one off the embayment, on the shelf (Shelf, S) and one in the middle sector of the embayment (Ría, R) (Fig. 1), were sampled during 3 seasons (1, winter; 2, spring; and 3 , summer), to cover a wide range of initial hydrographic and ecological conditions. We conducted 6 enrichment microcosm experiments: 2 in winter (Expts S1 and R1, February 2008), 2 in spring (Expts S2 and R2, April 2008), and 2 in summer (Expts S3 and R3, June and July 2008 respectively).

Vertical profiles down to 80 and $25 \mathrm{~m}$ (Shelf and Ría stations respectively) of water column temperature and salinity were obtained with an SBE 9/11 CTD probe attached to a rosette sampler. Surface seawater 


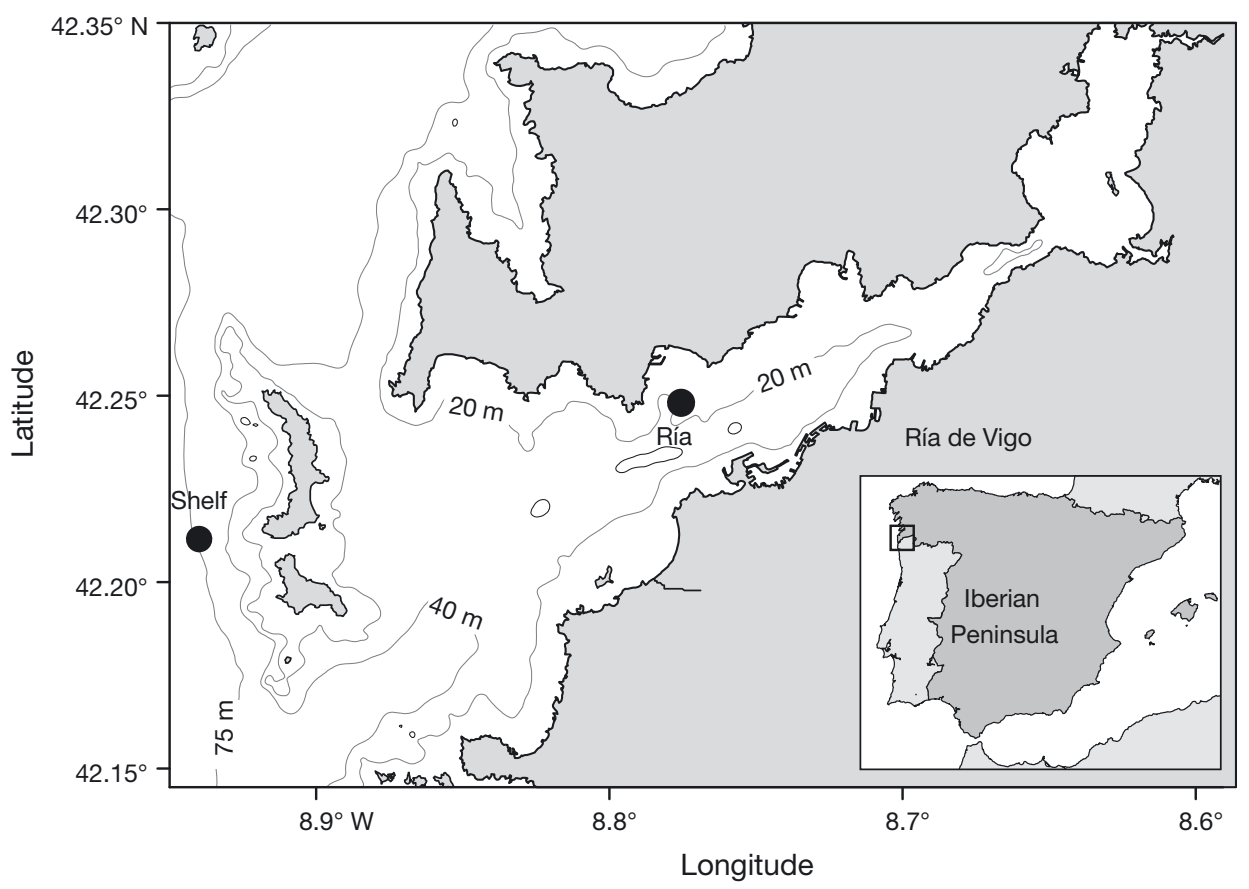

Fig. 1. The NW Iberian margin (inset) and locations of the stations that were sampled in the Ría de Vigo and on the shelf

samples (5 to $10 \mathrm{~m}$ ) were collected in 121 acid-cleaned Niskin bottles and filtered through a $200 \mu \mathrm{m}$ pore size mesh to remove larger zooplankton in order to ensure good replication, given the difficulty to homogeneously sample these organisms in 121 bottles. Subsequently, 121 acid-washed polycarbonate bottles were gently filled under dim light conditions.

The experimental design included duplicate bottles for a series of 4 treatment levels: (1) control treatment: no additions made; (2) inorganic addition treatment: $5 \mu \mathrm{mol} \mathrm{l}{ }^{-1}$ nitrate $\left(\mathrm{NO}_{3}{ }^{-}\right), 5 \mu \mathrm{mol} \mathrm{l}{ }^{-1}$ ammonium $\left(\mathrm{NH}_{4}{ }^{+}\right)$, $1 \mu \mathrm{mol} \mathrm{l} \mathrm{l}^{-1}$ phosphate $\left(\mathrm{HPO}_{4}{ }^{2-}\right)_{i}$ (3) organic addition treatment: $5 \mu_{\mathrm{mol} \mathrm{l}^{-1}}$ glucose and $5 \mu \mathrm{mol} \mathrm{l^{-1 }}$ of an equimolar mixture of 18 amino acids (all protein amino acids, except cysteine and tyrosine); (4) mixed addition treatment: combination of inorganic and organic additions. The nitrogen:phosphorus $(\mathrm{N}: \mathrm{P})$ ratio of these additions was $10: 1$ to $15: 1$ depending on the addition made (inorganic or mixed addition treatment), thus avoiding P-limited additions in the inorganic and mixed treatment. The $\mathrm{C}: \mathrm{N}$ ratio of these additions was ca. 3.3:1 to 10:1 depending on the addition made (mixed or organic addition). Organic additions were performed to simulate the increases of bioavailable organic $\mathrm{N}$ in atmospheric and/or continental discharge (Meybeck 1993, Peierls \& Paerl 1997, Seitzinger \& Sanders 1999). Furthermore, atmospheric deposition and river discharge have been demonstrated to contain not only organic $\mathrm{N}$ but also labile dissolved organic C (DOC) (Meybeck 1993, Jacobson et al. 2000,
Cauwet 2002, Jurado et al. 2008). We therefore added glucose and amino acids, as they are among the most abundant organic labile substances identified in seawater (Benner 2002, Bronk 2002). Despite its potentially important role, dissolved organic P (DOP) was not included in the organic addition as the fluxes of DOP are less well documented than those of C and N (Meybeck 1993, Cauwet 2002, Karl \& Björkman 2002).

The experimental bottles were maintained in a temperature-controlled room at in situ temperature $\left( \pm 0.1^{\circ} \mathrm{C}\right)$. Bottles were illuminated with cool white light from fluorescent tubes. The photoperiod ranged from $12 \mathrm{~h}$ light: $12 \mathrm{~h}$ dark to $14 \mathrm{~h}$ light: $10 \mathrm{~h}$ dark depending on the season of sampling, and the average photosynthetically active radiation (PAR) was $240 \mu \mathrm{E} \mathrm{m}^{-2} \mathrm{~s}^{-1}$. To prevent cell sedimentation, bottles were placed on rollers which rotated them at ca. $6 \mathrm{rpm}$. After prescreening, samples were incubated overnight on the rollers, and single nutrient additions were performed before the light was turned on. Initial conditions were measured just after the nutrient additions. Experiments lasted $3 \mathrm{~d}$ and samples were taken every $24 \mathrm{~h}$ to monitor changes in microbial community structure and metabolism.

Inorganic and organic nutrients. Aliquots for inorganic nutrient determinations (ammonium, nitrite, nitrate, phosphate, and silicate) were collected in $50 \mathrm{ml}$ polyethylene bottles and frozen at $-20^{\circ} \mathrm{C}$ until analysis by standard colorimetric methods with an Alpkem segmented flow analyzer (Hansen \& Grasshoff 1983). 
Water for the analysis of DOC was filtered through $0.2 \mu \mathrm{m}$ filters (Pall, Supor membrane Disc Filter) in an all-glass filtration system under positive pressure of $\mathrm{N}_{2}$, collected into pre-combusted $\left(450^{\circ} \mathrm{C}, 12 \mathrm{~h}\right) 10 \mathrm{ml}$ glass ampoules, and acidified with $\mathrm{H}_{3} \mathrm{PO}_{4}$ to $\mathrm{pH}<2$ before heat sealing. Samples were measured in a Shimadzu TOC-CVS analyzer (Pt-catalyst) following Álvarez-Salgado \& Miller (1998). Fluorescence measurements were performed at a constant room temperature of $25^{\circ} \mathrm{C}$ in a $1 \mathrm{~cm}$ quartz fluorescence cell in a Perkin Elmer LS 55 luminescence spectrometer. Fluorescence intensity was measured at a fixed excitation/emission wavelength of $280 \mathrm{~nm} / 350 \mathrm{~nm}$, which is characteristic of protein-like materials (Coble 1996). Following NietoCid et al. (2006), the spectrofluorometer was calibrated daily with tryptophan (Trp) in $0.1 \mathrm{~N}$ sulfuric acid. Fluorescence of dissolved organic matter (FDOM) was expressed in $\mu \mathrm{g} \mathrm{l}^{-1}$ equivalents of Trp (hereinafter: ppb Trp). Equivalent concentrations were determined by subtracting the average peak height from the $M Q$ blank height, and dividing by the slope of the standard curve.

Size-fractionated chlorophyll a (chl a). Size-fractionated chl a concentrations were measured in $150 \mathrm{ml}$ water samples that were filtered sequentially through $20,5,2$, and $0.2 \mu \mathrm{m}$ polycarbonate filters. After extraction with $90 \%$ acetone at $4{ }^{\circ} \mathrm{C}$ overnight in the dark, chl a fluorescence was determined using the non-acidification technique (Welschmeyer 1994), with a TD-700 Turner Designs fluorometer calibrated with pure chl $a$.

Photosynthetic efficiency $\left(F_{v} / F_{m}\right)$. Fast repetition rate (FRR) fluorescence measurements were made using a Chelsea Instruments Fast ${ }^{\text {tracka }}$ FRR fluorometer (Estévez 2007). Samples were adapted to dark conditions for 30 min in order to ensure relaxation of non-photochemical quenching. A single turnover protocol was used: a flash sequence consisting of a series of 100 saturation flashlets (1.34 $\mu$ s flash duration and $2.8 \mu$ s flash period) and a series of 20 relaxation flashlets (1.34 $\mu$ s flash duration and $51.6 \mu$ s flash period). Measurements of three $50 \mathrm{ml}$ replicates were performed in dark conditions in the FRR fluorometer dark chamber (30 acquisitions of 8 averaged flash sequences). Autogaining mode was used in order to ensure that the optimal gain was being applied and to avoid saturation problems. Blanks (water samples filtered through Millipore glass-fiber filters) were measured at fixed gains for every addition treatment every sampling day. Data were processed using the Fast ${ }^{\text {tracka }}$ postprocessing software Frs (provided by Chelsea Instruments). The ratio $F_{\mathrm{v}} / F_{\mathrm{m}}$ was calculated for each replicate, and then a mean of the 3 values was obtained for each microcosm bottle.

Primary production (PP). Four $75 \mathrm{ml}$ acid-cleaned polystyrene bottles ( 3 light and 1 dark) were filled with seawater and spiked with $185 \mathrm{kBq}(5 \mu \mathrm{Ci}) \mathrm{NaH}^{14} \mathrm{CO}_{3}$.
Samples were incubated for 3 to $4 \mathrm{~h}$ in the same incubation chamber as the experimental bottles. After the incubation period, samples were sequentially filtered through $20,5,2$, and $0.2 \mu \mathrm{m}$ polycarbonate filters at very low vacuum $(<50 \mathrm{~mm} \mathrm{Hg})$. Filters were processed to assess ${ }^{14} \mathrm{C}$ incorporation as described in Marañón et al. (2001). Hourly PP rates presented in the present study correspond to PP rates in the particulate fraction. Given that the incubations lasted 3 to $4 \mathrm{~h}$, they can be considered to be close to gross rates. Daily gross PP rates estimated using a correction factor for phytoplankton respiration of $20 \%$ and a percentage of extracellular release (PER) of $20 \%$ (Marañón et al. 2004) were used for the calculation of the PP to community respiration $(\mathrm{CR})$ ratio $(\mathrm{PP} / \mathrm{CR})$.

Bacterial heterotrophic production (BP). The $\left[{ }^{3} \mathrm{H}\right]$ leucine incorporation method (Kirchman et al. 1985), modified as described by Smith \& Azam (1992), was used to determine leucine (Leu) incorporation rates (LIR). Samples were incubated for $1 \mathrm{~h}$ in the same incubation chamber as the experimental bottles. Eight dilution experiments, 4 in the Ría (Expt R3) and 4 on the Shelf (Expt S3), were performed in order to determine empirical Leu to $\mathrm{C}$ conversion factors for the control, inorganic, organic, and mixed nutrient treatment, following methods detailed elsewhere (Calvo-Díaz \& Morán 2009). No significant differences in conversion factors were found between both sampling locations ( $t$-test, $\mathrm{p}>0.05$ ). The mean conversion factors derived were: $2.6 \pm 1.1 \mathrm{~kg} \mathrm{C} \mathrm{mol} \mathrm{Leu}{ }^{-1}$ for the control, $1.6 \pm$ $0.6 \mathrm{~kg} \mathrm{C} \mathrm{mol} \mathrm{Leu}{ }^{-1}$ for the inorganic treatment, $3.3 \pm$ $0.9 \mathrm{~kg} \mathrm{C} \mathrm{mol} \mathrm{Leu}^{-1}$ for the organic treatment, and $4.4 \pm$

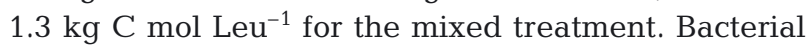
growth efficiency (BGE) was calculated as: BP/(BP + $\mathrm{BR})$, where $\mathrm{BR}$ is bacterial respiration.

In vivo electron transport system (ETS). ETS activity rate was used as an estimator of CR. Size-fractionated in vivo ETS activity rates were measured using the in vivo INT (2-para (iodo-phenyl)-3(nitrophenyl)5(phenyl)-tetrazolium chloride) method (MartínezGarcía et al. 2009). Four $100 \mathrm{ml}$ dark bottles were filled from each microcosm bottle. One bottle was immediately fixed by adding formaldehyde $(2 \% \mathrm{w} / \mathrm{v}$ final concentration) and used as killed-control. Samples were incubated at the same temperature as the microcosm bottles in dark conditions during $1 \mathrm{~h}$. After incubation, samples were filtered sequentially through 0.8 and $0.2 \mu \mathrm{m}$ pore size polycarbonate filters. BR was operationally defined as ETS activity $<0.8 \mu \mathrm{m}$ (Robinson 2008). In order to transform ETS activity into $C$ respiration, a CR/ETS ratio of 12.8 (Martínez-García et al. 2009) and a respiratory quotient (RQ) of 0.8 (Williams \& del Giorgio 2005) were used.

Autotrophic and heterotrophic picoplankton. The abundance of picoautotrophs (Synechococcus, Pro- 
chlorococcus, and picoeukaryotes) and heterotrophic bacteria was determined with a Becton Dickinson FACSCalibur flow cytometer equipped with a laser emitting at 488 nm (Calvo-Díaz \& Morán 2006). Picoplankton samples $(1.8 \mathrm{ml})$ were preserved with $1 \%$ paraformaldehyde plus $0.05 \%$ glutaraldehyde, and frozen at $-80^{\circ} \mathrm{C}$ until analysis. Aliquots of the same sample were used for the analysis of picophytoplankton $(0.6 \mathrm{ml})$ and heterotrophic bacteria $(0.4 \mathrm{ml})$. Prior to analysis, heterotrophic bacteria were stained with 2.5 mM SybrGreen DNA fluorochrome.

Picoplankton groups were identified on the basis of their fluorescence and light side scatter (SSC) signatures. Synechococcus and Prochlorococcus cyanobacteria and 3 groups of eukaryotic cells (small and large picoeukaryotes plus cryptophytes) were identified in plots of SSC versus red fluorescence (FL3, >650 nm), and orange fluorescence (FL2, $585 \mathrm{~nm}$ ) versus FL3. Small cryptophytes showed higher SSC and FL2 signals than Synechococcus. More details are given in Calvo-Díaz \& Morán (2006). Two groups of heterotrophic bacteria were distinguished based on their green fluorescence (FL1, $530 \mathrm{~nm}$ ) as a proxy for nucleic acid content: low (LNA) and high nucleic acid (HNA) content bacteria.

The empirical calibrations between SSC and mean cell diameter described in Calvo-Díaz \& Morán (2006) were used to estimate biovolume (BV) of picoautotrophs and heterotrophic bacteria. BV was finally converted into biomass by using the volume-to-C conversion factors from Worden et al. (2004) for picophytoplankton and the allometric relationship of Norland (1993): fg $\mathrm{C} \mathrm{cell}^{-1}=120 \times \mathrm{BV}^{0.72}$ for heterotrophic bacteria.

Nano- and microphytoplankton identification. For the analysis of larger cells under the microscope, $100 \mathrm{ml}$ samples were preserved with Lugol's solution. After sedimentation of a subsample (5 to $100 \mathrm{ml}$ ), cells were identified, counted, and measured following the method of Utermöhl (Lund et al. 1958) at $100 \times$ and $200 \times$ magnification on an Olympus IX50 inverted microscope connected to an NIS-Elements BR 3.0 image analysis program. Cell biovolume for each species was estimated from direct measurements of fixed cells under the microscope and by approximating the cells' shape to the closest geometric shape following Olenina et al. (2006) (whenever it was not possible to obtain the third dimension it was taken from Olenina et al. 2006). Finally, C-to-volume relationships were extracted from Menden-Deuer \& Lessard (2000).

Statistical analysis. Repeated-measures ANOVA (RMANOVA) was conducted to assess time (incubation time, within-subject factor), treatment (control, inorganic, organic, and mixed treatments, betweensubject factor), and experiment (the 6 different experi- ments performed, between-subject factor) effects. For each variable, data from the 4 treatments, the 6 experiments, and all sampling times were pulled together for the RMANOVA test. All data fitted a normal distribution (Kolmogorov-Smirnov test); however, even after log or arcsine data transformation, the homogeneity of covariance matrices failed for some data sets or variables. For the latter case we applied the Huynh-Feldt adjustment to correct p-values (Scheiner \& Gurevitch 1993). A Bonferroni post hoc test was conducted to assess the direction (stimulation or inhibition) of the effect of the addition treatments on the microbial variables. In order to estimate and compare the magnitude of the effect of different nutrient additions on the biomasses and rates, we calculated response ratios (RR) as $\mathrm{AT} / \mathrm{C}$, where AT and $\mathrm{C}$ are the time-integrated value of the variable over the $72 \mathrm{~h}$ incubation in the addition treatment and the control, respectively. In the case of biomasses, time-averaged values were used. It is worth mentioning that no differences were found either in the time, experiment, and treatment effects (RMANOVA) or in the direction of the nutrient addition effect over all the variables (Bonferroni post hoc test) using data from 0 to 24,48 , or $72 \mathrm{~h}$.

\section{RESULTS}

\section{Initial conditions}

Initial conditions for each experiment are presented in Table 1 and Fig. 2. Different hydrographic conditions were found during each survey. In winter (Expts S1 and R1), low surface temperature and high nutrient concentration indicate intense vertical mixing. Spring surveys (Expts S2 and R2) were performed after an upwelling event. In Expt R2, surface salinity was 33.7, indicating important continental inputs at this location at the time of sampling. Summer samplings (Expts S3 and R3) coincided with an upwelling event.

Nitrate and nitrite concentrations varied 1 order of magnitude between stations and seasons (from 0.48 to $10 \mu \mathrm{mol} \mathrm{l} \mathrm{l}^{-1}$ and from 0.03 to $0.8 \mu \mathrm{mol} \mathrm{l}^{-1}$ respectively). Phosphate initial concentrations ranged from 0.04 to $1.19 \mathrm{mmol} \mathrm{l}^{-1}$ and were always higher in the Ría than in shelf waters. Silicate initial concentrations ranged from

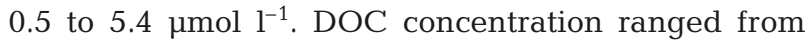

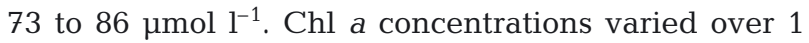
order of magnitude and ranged from 0.18 to $2.10 \mathrm{\mu g}^{-1}$.

Nanophytoplankton (2 to $20 \mu \mathrm{m}$ ), mainly composed of dinoflagellates, dominated the phytoplankton community in terms of chl a concentration in Expts S1 and S3, whereas $>20 \mu \mathrm{m}$ phytoplankton, mainly formed by diatoms, dominated in Expts R1, R2, R3, and S2 
Table 1. Summary of initial conditions for each experiment. Sampling depth was 5 to $10 \mathrm{~m}$. DOC: dissolved organic carbon; FDOM: fluorescence of dissolved organic matter. Trp: tryptophan

\begin{tabular}{|c|c|c|c|c|c|c|c|c|c|c|}
\hline \multirow{2}{*}{ Expt } & \multirow{2}{*}{$\begin{array}{c}\text { Surface } \\
\text { temperature } \\
\left({ }^{\circ} \mathrm{C}\right)\end{array}$} & \multirow{2}{*}{$\begin{array}{l}\text { Surface } \\
\text { salinity }\end{array}$} & \multirow{2}{*}{$\begin{array}{l}\text { Chl } a \\
\left(\mu g l^{-1}\right)\end{array}$} & \multicolumn{7}{|c|}{ Surface nutrients } \\
\hline & & & & $\begin{array}{c}\mathrm{NO}_{3}^{-} \\
\left(\mu \mathrm{mol} \mathrm{l} l^{-1}\right)\end{array}$ & $\begin{array}{c}\mathrm{NO}_{2}^{-} \\
\left(\mu \mathrm{mol} \mathrm{l} l^{-1}\right)\end{array}$ & $\begin{array}{c}\mathrm{NH}_{4}^{+} \\
\left(\mu \mathrm{mol} \mathrm{l}^{-1}\right)\end{array}$ & $\begin{array}{c}\mathrm{HPO}_{4}^{-2} \\
\left(\mu \mathrm{mol} \mathrm{l}^{-1}\right)\end{array}$ & $\begin{array}{c}\mathrm{SiO}_{2} \\
\left(\mu \mathrm{mol} \mathrm{l}^{-1}\right)\end{array}$ & $\begin{array}{l}\text { FDOM } \\
\text { (ppb Trp) }\end{array}$ & $\begin{array}{c}\text { DOC } \\
\left(\mu \mathrm{mol} l^{-1}\right)\end{array}$ \\
\hline S1 & 14.0 & 35.2 & 1.8 & 2.3 & 0.09 & 0.23 & 0.08 & 4.1 & 7.6 & 85 \\
\hline $\mathrm{S} 2$ & 14.6 & 35.4 & 0.3 & 0.48 & 0.03 & 1.4 & 0.04 & 0.5 & 6.9 & 74 \\
\hline S3 & 16.3 & 35.7 & 0.2 & 0.93 & 0.81 & 1.6 & 0.19 & 2.1 & 5.5 & 82 \\
\hline R1 & 13.5 & 35.0 & 0.7 & 9.6 & 0.32 & 5.5 & 1.19 & 5.4 & 8.9 & 86 \\
\hline R2 & 14.3 & 33.7 & 1.3 & 2.4 & 0.11 & 0.9 & 0.14 & 3.5 & 9.3 & 80 \\
\hline R3 & 15.2 & 35.6 & 2.1 & 3.6 & 0.25 & 1.5 & 0.52 & 4.4 & 7.9 & 73 \\
\hline
\end{tabular}
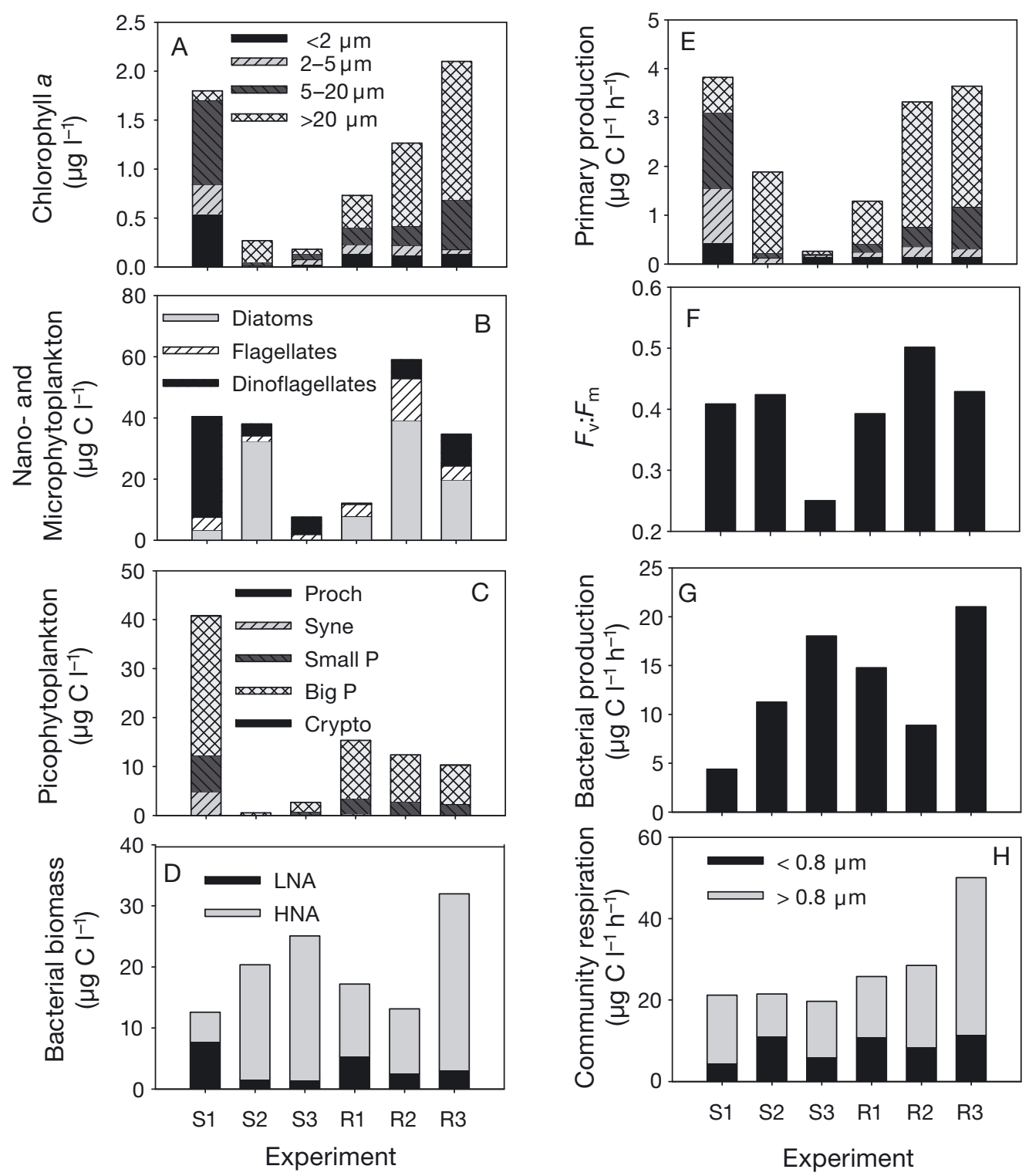

Fig. 2. Initial biological conditions at the sampling stations. (A) Size-fractionated chl a. (B) Nano- and microphytoplankton biomass. (C) Picophytoplankton biomass. Proch: Prochlorococcus; Syne: Synechococcus; Small P: small picoeukaryotes; Big P: big picoeukaryotes; Crypto: Cryptophyceae. (D) Heterotrophic bacterial biomass. LNA: low nucleic acid content; HNA: high nucleic acid content. (E) Size-fractionated primary production. (F) Photosynthetic efficiency $\left(F_{\mathrm{v}} / F_{\mathrm{m}}\right)$. (G) Bacterial production. (H) Sizefractionated community respiration estimated from in vivo electron transport system (ETS) activity 
(Fig. 2A,B). Large picoeukaryotes dominated the picophytoplankton size class in all experiments (Fig. 2C).

The variability in hourly gross PP was similar to that of chl a concentration data. PP rates ranged from 0.27 to $3.82 \mu \mathrm{g} \mathrm{C}^{-1} \mathrm{~h}^{-1}$. The relative contribution of the different size fractions to total PP paralleled that found in chl a concentration. Photosynthetic efficiency measured as $F_{\mathrm{v}} / F_{\mathrm{m}}$ was ca. 0.4 to 0.5 in all the experiments except for Expt S3, where a very low value was recorded (0.25). Bacterial biomass (BB) ranged from

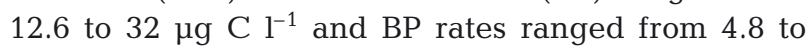
$15.9 \mu \mathrm{g} \mathrm{Cl}^{-1} \mathrm{~d}^{-1}$. BB was highest in summer. HNA bacteria dominated bacterial community biomass in all experiments except for Expt S1. CR, estimated from in vivo ETS activity, ranged from 19.8 to $50.1 \mu \mathrm{g} \mathrm{C} \mathrm{l}^{-1} \mathrm{~d}^{-1}$. The contribution of $\mathrm{BR}(<0.8 \mu \mathrm{m}$ fraction) to $\mathrm{CR}$ ranged from 21 to $52 \%$.

Three different ratios, the initial phytoplankton biomass (PhytoB) relative to BB (PhytoB/BB_i), the initial daily gross PP to daily $C R$ ratio (PP/CR_i), and the initial daily gross PP to daily BP ratio (PP/BP_i), were calculated to synthetically describe the initial microbial community structure and metabolism. The PhytoB/ $\mathrm{BB}$ _i ratio changed between experiments, and ranged from 0.4 to 6.5. The metabolic balance at initial conditions (PP/CR_i) (from 0.3 to 3 ) and the PP/BP_i ratio (from 0.3 to 14.6 ) were also highly variable among experiments (Fig. 3).

Statistically significant linear relationships were found between PhytoB/BB_i and PP/BP_i $\left(n=6, \mathrm{r}^{2}=\right.$ 0.84, $\mathrm{p}=0.01$ ) (Fig. $3 \mathrm{~A}$ ) and between PhytoB/BB_i and PP/CR_i ( $\left.n=6, r^{2}=0.82, p=0.012\right)$ (Fig. 3B).

\section{Nutrient concentration}

Nitrate and ammonium were exhausted in the mixed treatment by the end of the incubation time in Expts R1, R2, R3, and S1 (Fig. 4A,B). In all the experiments, phosphate was quickly consumed during the first incubation day in the mixed treatment although it was not exhausted in any of the experiments. Phosphate decreased to a lesser extent in the inorganic treatment (Fig. 4C). Overall, silicate concentration remained rather constant or slightly decreased throughout the incubation except for Expt R1, in which a sharp decreased of silicate was observed in all the treatments (data not shown). The time course of FDOM shows that the added DON was consumed completely in the mixed treatment in all experiments. In the organic treatment it was consumed completely in Expts R1, R2, and R3 and to a lesser extent in Expts S1, S2, and S3 (Fig. 4D). DOC concentrations sharply decreased during the first incubation day in the mixed treatment. Decreases in DOC concentration in the organic treat-
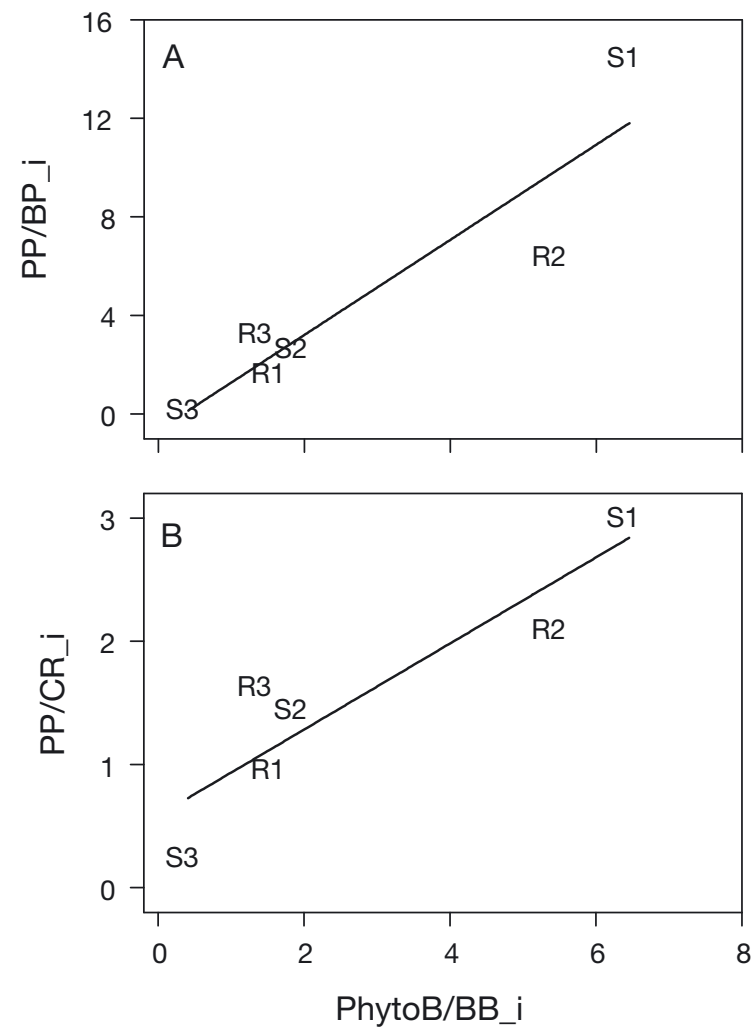

Fig. 3. Initial phytoplankton biomass to bacterial biomass ratio (PhytoB/BB_i) versus: (A) initial primary production to bacterial production ratio (PP/BP_i) and (B) initial primary production to community respiration ratio (PP/CR_i), for the 6 experiments (R1 to R3 and $\mathrm{S} 1$ to $\mathrm{S} 3$ )

ment paralleled those in the mixed treatment in Expts S3, R1, R2, and R3 and were less important in Expts S1 and S2 (Fig. 4E).

\section{Autotrophic responses to nutrient additions}

Different phytoplankton responses were recorded in the 6 experiments (Fig. 5). Three different patterns of response were found, although the largest responses were always observed after the mixed additions (Bonferroni post hoc test, $\mathrm{p}<0.05$; Table 2).

Similar responses were registered in Expts S1, R1, R2, and R3 (Fig. 5). In these experiments, chl $a$ and PP considerably increased relative to the control after mixed additions (significantly increased in Expts R1 and R3; Bonferroni post hoc test, p < 0.001) and smaller responses were registered after inorganic and/or organic additions. The magnitude of the responses (response ratios, $\mathrm{RR}$ ) in the mixed treatment varied between experiments for $\mathrm{chl} a$ ( $\mathrm{chl} a_{\mathrm{RR}}$ from 2.2- to 3.4-fold) and for $\mathrm{PP}$ ( $\mathrm{PP}_{\mathrm{RR}}$ from 1.9- to 5.5-fold). In Expt $\mathrm{S} 2$, chl $a$ and PP similarly increased after inorganic 

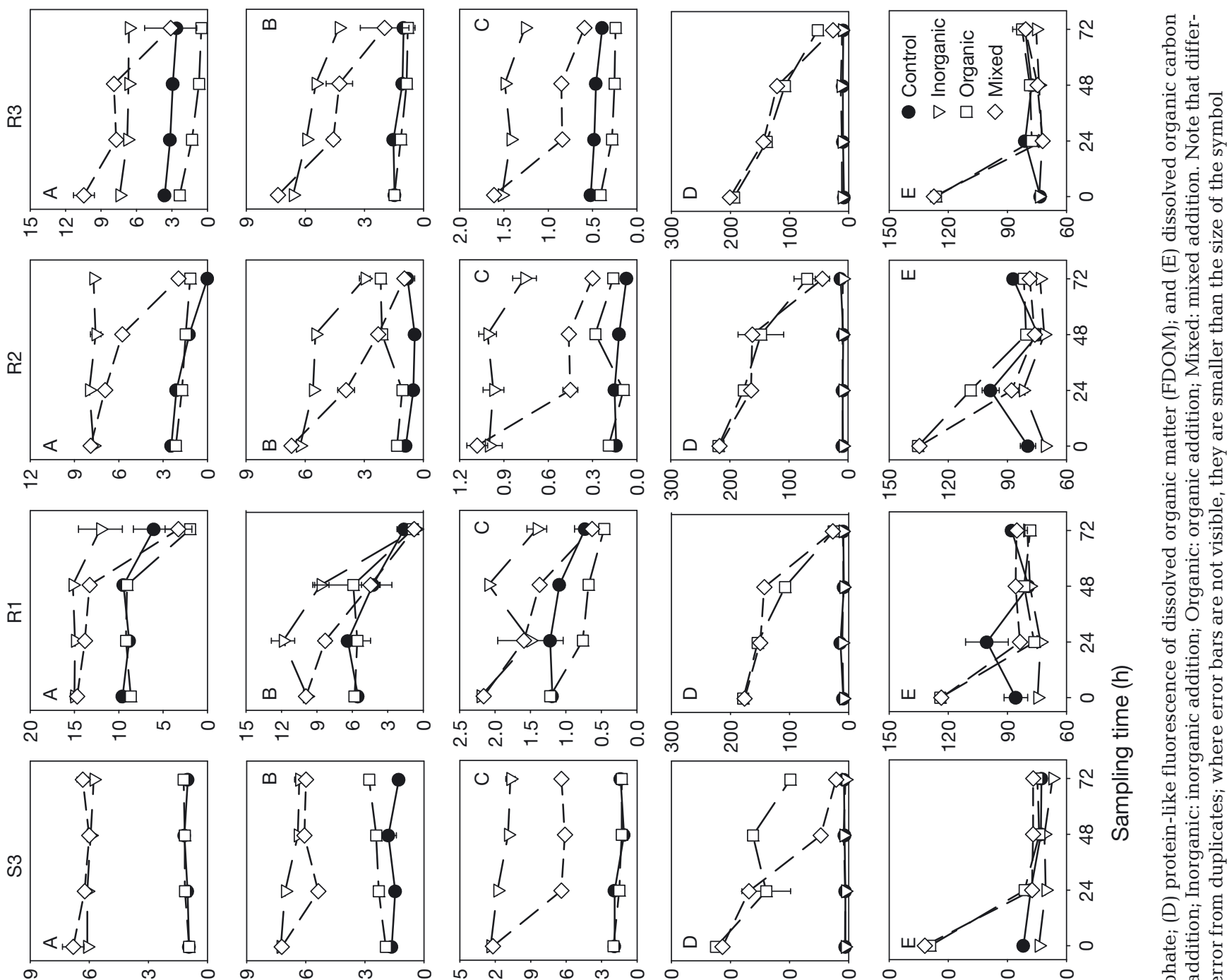

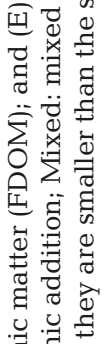
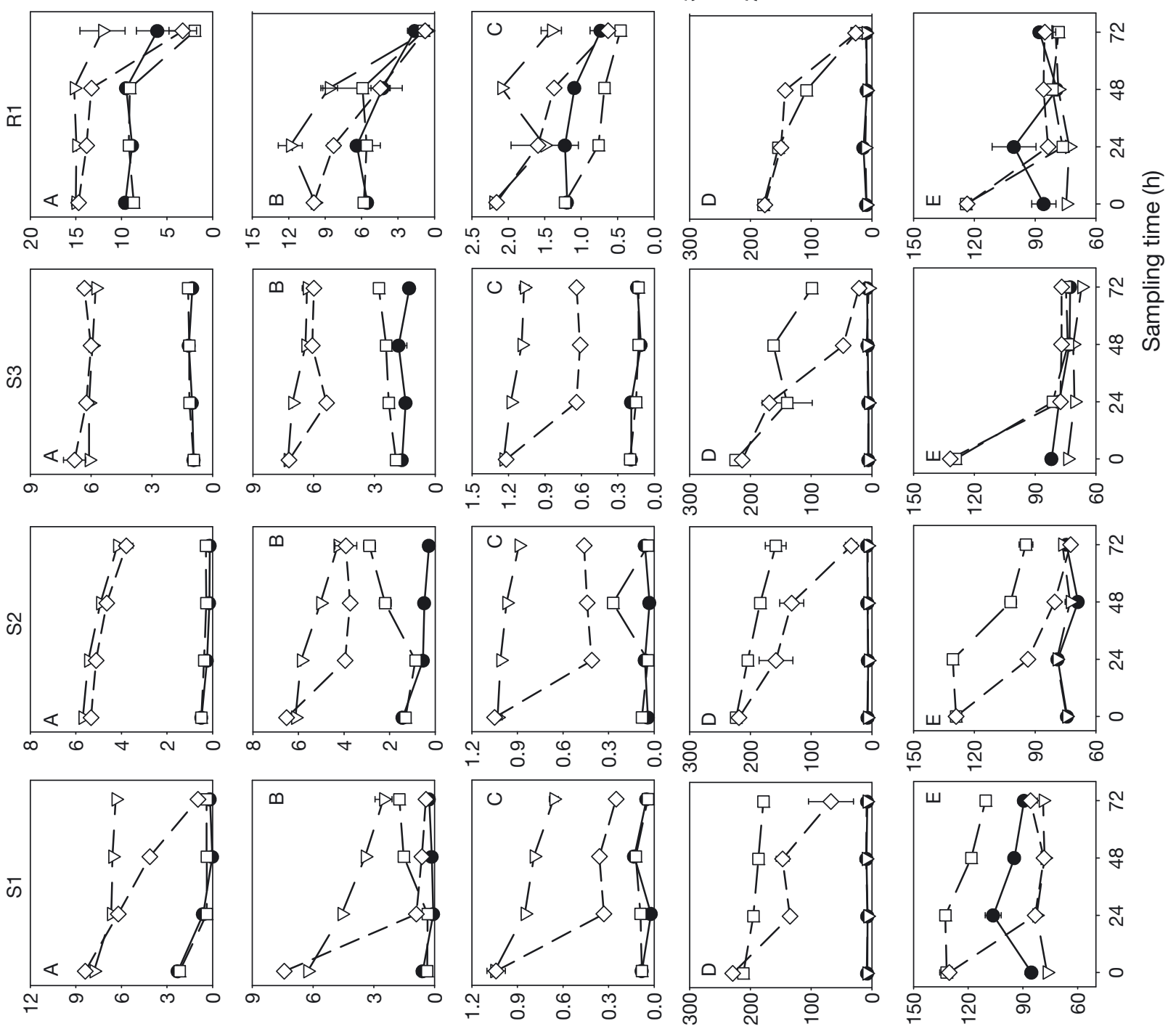

$\mathrm{NO}_{3}^{-}$
$\left(\mu \mathrm{mol}{ }^{-1}\right)$

$\underset{\left(\mu \mathrm{mol} l^{-1}\right)}{\mathrm{NH}_{4}^{+}}$

$\mathrm{PO}_{4}^{-3}$

$\left(\mu \mathrm{mol} \mathrm{I}{ }^{-1}\right)$
Protein-like FDOM (ppb Trp)

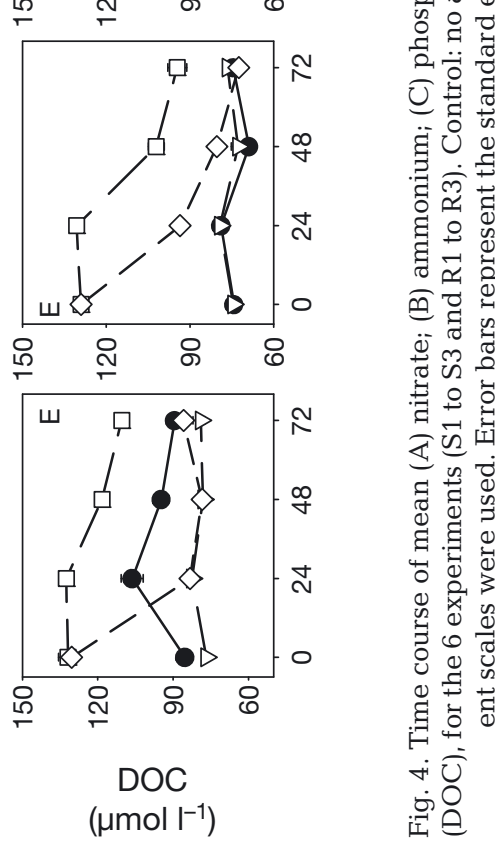



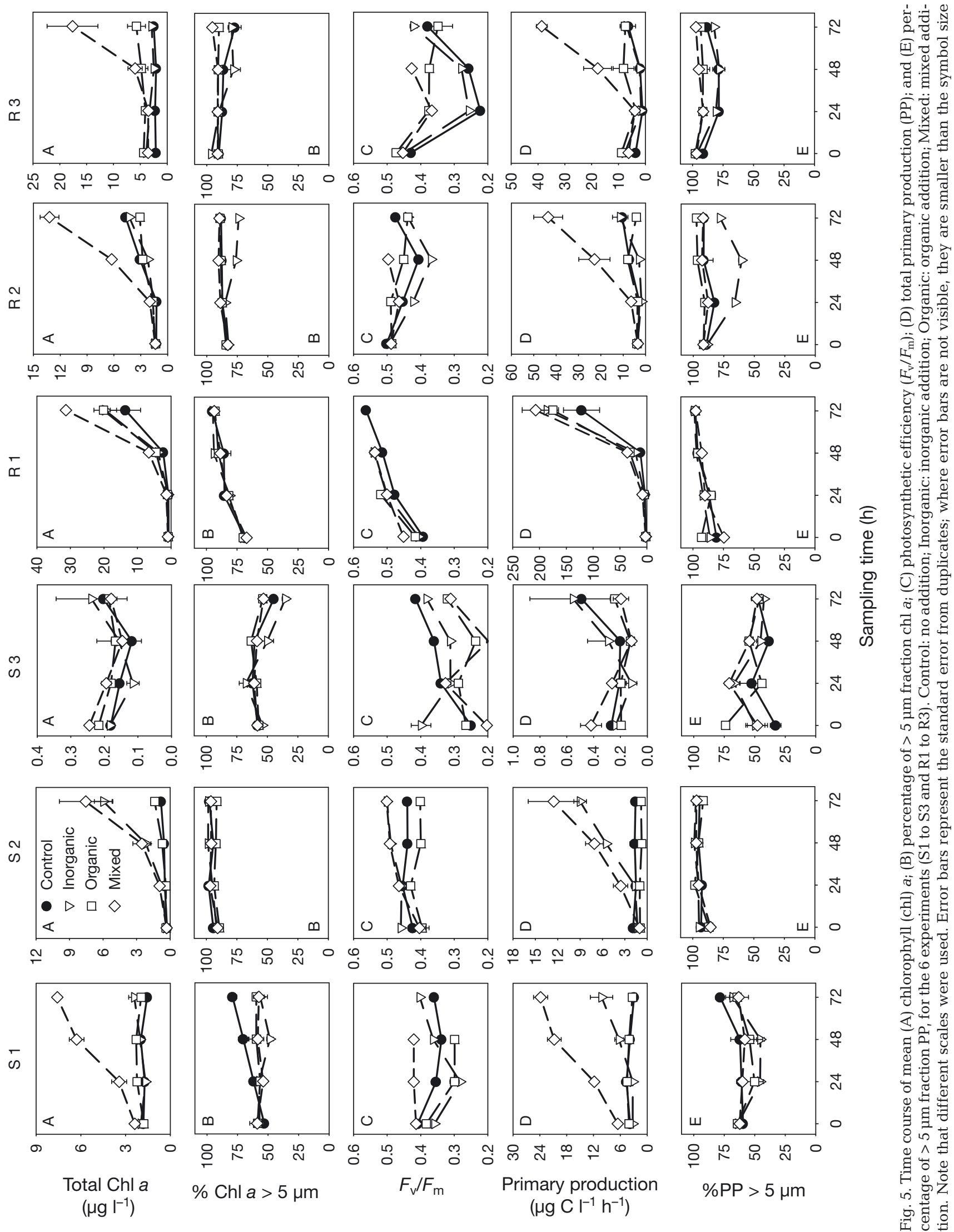

Total Chl a $\left(\mu \mathrm{g} \mathrm{I}^{-1}\right)$

$\% \mathrm{Chl} a>5 \mu \mathrm{m}$
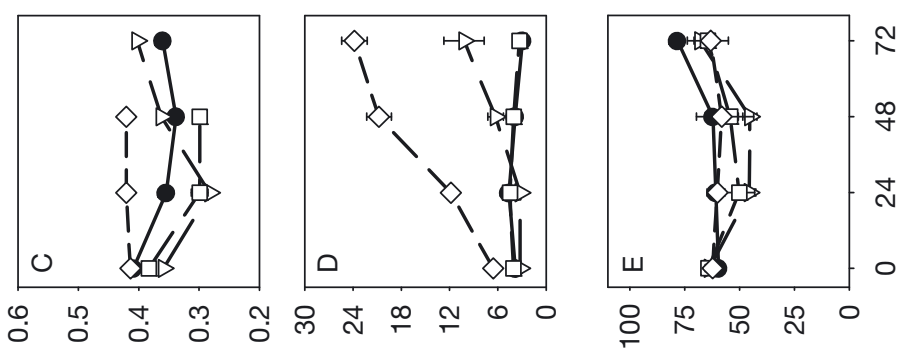

Primary production $\left(\mu \mathrm{C} \mathrm{I}^{-1} \mathrm{~h}^{-1}\right)$

$\% \mathrm{PP}>5 \mu \mathrm{m}$

它范。 
(4.4- and 2.5-fold respectively) and mixed additions (5.4- and 3.6-fold respectively) (Fig. 5A,D). No response was found in Expt S3 (Fig. 5) (Bonferroni post hoc test, $\mathrm{p}>0.05$ ).

No major changes were found in phytoplankton biomass size structure as a response to nutrient additions in any of the experiments (Fig. 5B,E). Microphytoplankton ( $>20 \mu \mathrm{m}$ ) dominated in Expts R1, R2, R3, and S2 and nanophytoplankton (2 to $20 \mu \mathrm{m}$ ) dominated in Expts S1 and S3 before (Fig. 2) and after the additions (data not shown). For simplicity we have represented only the contribution of $>5 \mu \mathrm{m}$ phytoplankton to both chl $a$ and PP. No significant changes were found in the contribution of $>5 \mu \mathrm{m}$ phytoplankton to both chl $a$ and PP after the additions (Bonferroni post hoc test, p > 0.05; Table 2). Similarly, phytoplankton community composition did not greatly change as a result of the nutrient additions. Diatoms dominated the phytoplankton community at the end of the experiment in all the treatments in Expts R1, R2, R3 (except in the inorganic treatment), and S2, whereas in Expts S1 and S3 the final phytoplankton community was dominated by dinoflagellates, flagellates, and picophytoplankton in all treatments (data not shown).

Photosynthetic efficiency $\left(F_{\mathrm{v}} / F_{\mathrm{m}}\right)$ followed a similar pattern as chl $a$ and PP (Fig. $5 C$ ). $F_{\mathrm{v}} / F_{\mathrm{m}}$ decreased relative to control in the organic treatment in Expts $\mathrm{S} 1$ and $\mathrm{S} 2$. A decrease in $F_{\mathrm{v}} / F_{\mathrm{m}}$ in all the addition treatments relative to control was also measured in Expt S3.

Table 2. Summary of the global effect of the different additions on biological variables (repeated-measures ANOVA [RMANOVA] and Bonferroni post hoc tests). 0: no significant effect; +++ : significant effect at $\mathrm{p}<0.001$. Chl a: chlorophyll a concentration; \% Chl $a>5 \mu \mathrm{m}$ : contribution of chl $a$ in the fraction $>5 \mu \mathrm{m}$ to total chl $a_{i}$ PP: primary production; \% PP $>5 \mu \mathrm{m}$ : contribution of PP in the fraction $>5 \mu \mathrm{m}$ to total PP; $F_{\mathrm{v}} / F_{\mathrm{m}}$ : photosynthetic efficiency; BB: heterotrophic bacterial biomass; HNA: high nucleic acid content bacteria; BP: bacterial production; BR: bacterial respiration (estimated from in vivo electron transport system [ETS] activity due to the fraction $<0.8 \mu \mathrm{m}$ ); BGE: bacterial growth efficiency; CR: community respiration (estimated from total in vivo ETS activity)

\begin{tabular}{|lccc|}
\hline Variable & $\begin{array}{c}\text { Inorganic } \\
\text { addition }\end{array}$ & $\begin{array}{c}\text { Organic } \\
\text { addition }\end{array}$ & $\begin{array}{c}\text { Mixed } \\
\text { addition }\end{array}$ \\
\hline $\mathrm{Chl} a$ & 0 & 0 & +++ \\
$\% \mathrm{Chl} a>5 \mu \mathrm{m}$ & 0 & 0 & 0 \\
$\mathrm{PP}$ & 0 & 0 & +++ \\
$\% \mathrm{PP}>5 \mu \mathrm{m}$ & 0 & 0 & 0 \\
$F_{\mathrm{v}} / F_{\mathrm{m}}$ & 0 & 0 & 0 \\
$\mathrm{BB}$ & 0 & +++ & +++ \\
$\mathrm{HNA} / \mathrm{BB}$ & 0 & +++ & +++ \\
$\mathrm{BP}$ & 0 & +++ & +++ \\
$\mathrm{BR}(<0.8 \mu \mathrm{m}$ ETS $)$ & 0 & 0 & +++ \\
$\mathrm{BGE}$ & 0 & 0 & +++ \\
$\mathrm{CR}($ total ETS $)$ & 0 & +++ & +++ \\
\hline
\end{tabular}

We lack $F_{\mathrm{v}} / F_{\mathrm{m}}$ data from some bottles for the last incubation day ( $t=72 \mathrm{~h}$ ) due to saturation of the FRR fluorescence measurements.

The statistical analysis showed that the incubation time (within-subject factor) as well as the experiment (i.e. initial conditions) and the addition treatment (between-subjects factors) had a significant effect on chl $a$ and PP (RMANOVA, p < 0.001). Mixed additions resulted in a significant increase in total chl $a$ and PP (Bonferroni post hoc test, $\mathrm{p}<0.05$; Table 2).

\section{Heterotrophic responses to nutrient additions}

The response of heterotrophic bacteria to nutrient additions differed among experiments (RMANOVA, $p<0.001$ ) (Fig. 6). Three different patterns of response were found, although the largest responses were always registered after the mixed additions (Bonferroni post hoc test, $\mathrm{p}<0.001$ ).

The first pattern was observed in Expts S1 and S2 where enhanced $\mathrm{BB}$ and $\mathrm{BP}$ relative to the control was only observed after mixed additions $\left(\mathrm{BB}_{\mathrm{RR}}\right.$ and $\mathrm{BP}_{\mathrm{RR}} \mathrm{up}$ to 4.6- and 33.6-fold respectively) (Bonferroni post hoc test, $\mathrm{p}<0.001$ ). In contrast, organic and mixed treatments resulted in similar increases (Bonferroni post hoc test, $\mathrm{p}>0.05$ ) in BB and BP (up to 3.5- and 23.3-fold respectively) in Expts R1 and R3. Finally, in Expts S3 and R2, BB and BP significantly increased (Bonferroni post hoc test, $\mathrm{p}<0.001$ ) after mixed addition (up to 4.6and 25-fold respectively) and to a lesser extent after organic addition (3.3- and 14.5-fold respectively) (Fig. 6A,C) (Bonferroni post hoc test, p < 0.01). The biomass contribution of high-DNA bacteria (HNA/BB ratio) significantly increased after organic and mixed additions (Bonferroni post hoc test, p < 0.05; Table 2), reaching values of up to 0.99 (Fig. 6B).

$\mathrm{BR}$ responses to the additions followed the same pattern as BB (Fig. 6). BR significantly increased after mixed additions (Bonferroni post hoc test, $\mathrm{p}<0.001$; Table 2) in all the experiments (up to 11.8-fold in Expt S3), whereas BR increases were registered after organic additions in Expts R1 and R3 (6.6- and 3.8-fold respectively) (Fig. 6D) (significant in Expt R1: Bonferroni post hoc test, $\mathrm{p}<0.01$ ).

BGE did not significantly increase (Expts S2, S3, and R2) relative to control when inorganic nutrients were added in any of the experiments (Bonferroni post hoc test, $\mathrm{p}>0.05$ ) (Fig. 6E). The organic addition caused increase (up to 1.7-fold) (Expts S3, R1, R2, and R3), decrease (Expt S2), or no change (Expt S1) in BGE relative to control (Fig. 6E). After the mixed treatment, BGE significantly increased (Bonferroni post hoc test, $\mathrm{p}<0.05$; Table 2) relative to control (from 1.2- to 2-fold) in all the experiments (Fig. 6E). 


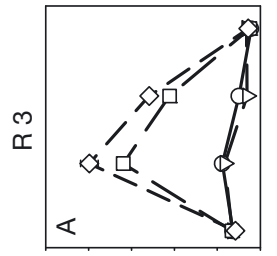

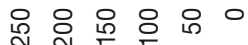

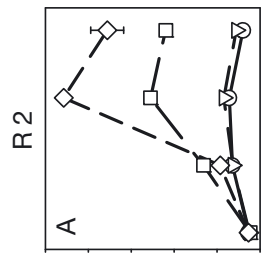

융ㅇㅇㅇㅇㅇㅇㅇㅇ

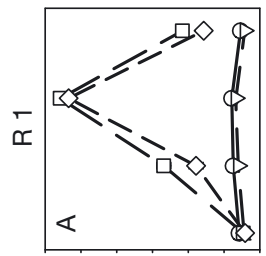

응ㅎํㅇㅇㅇㅇ

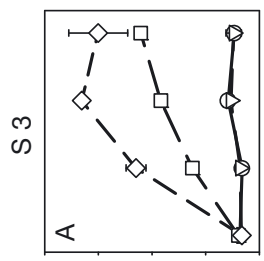

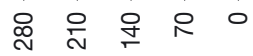

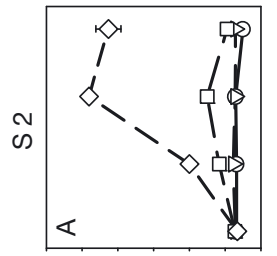

유용 \&

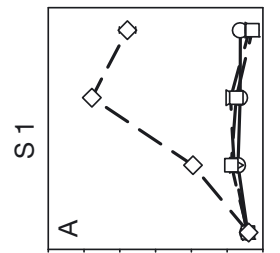

운웡ㅇㅇ

$\mathrm{BB}$

$\left(\mu \mathrm{C} \mathrm{I}^{-1}\right)$
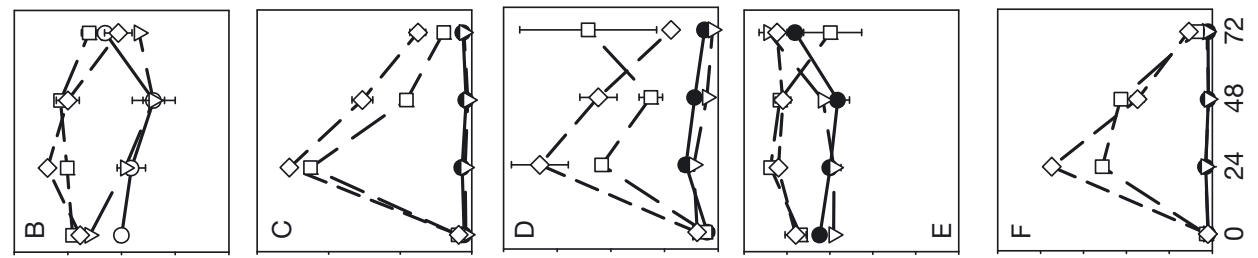

융
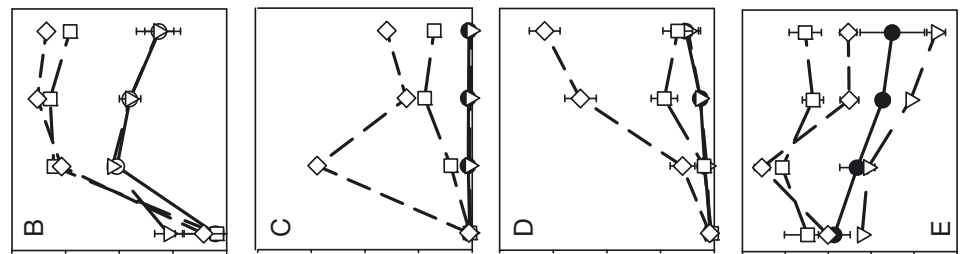

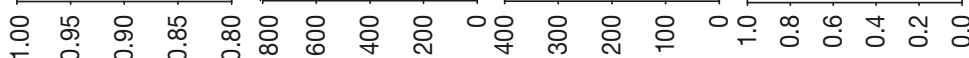
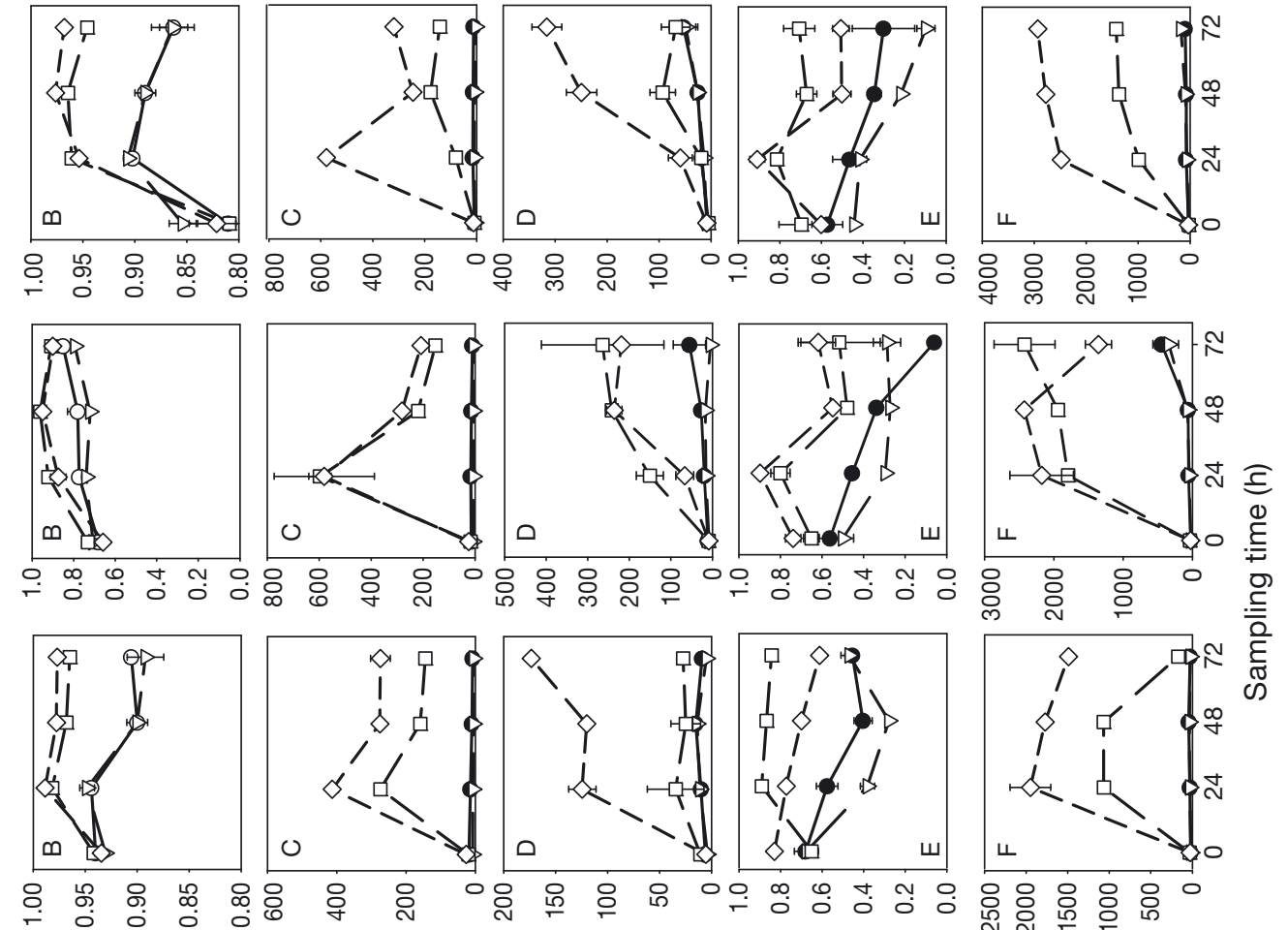

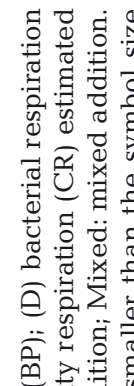

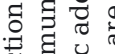

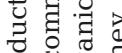

윰

글 물

ฮै สำ

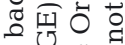

Uथี

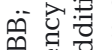

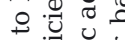

安进寻

至 둑융

.

ฮ :

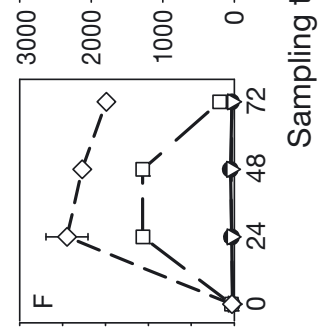

$\pi$

도요용

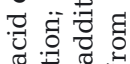

월 要

च

둥

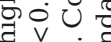

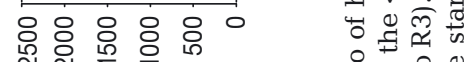
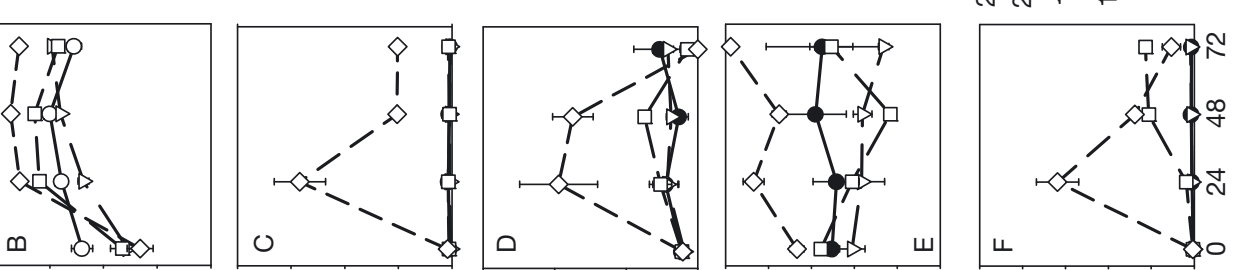

의

너묘

ฮ.

$\ddot{\nabla}$ 范

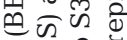

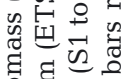

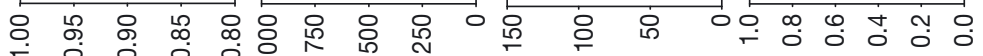

융ㅇㅇㅇㅇㅇㅇ
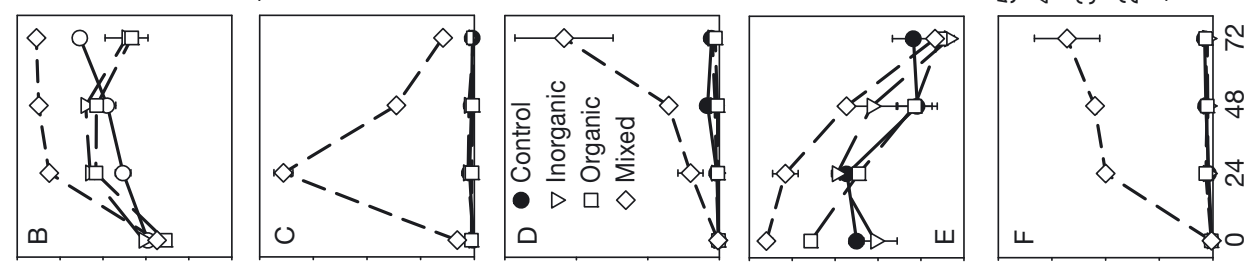

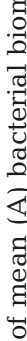
造嘀

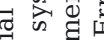

屯ै

更氜 0

뎌워

过营

o

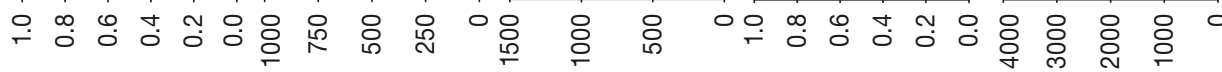

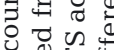

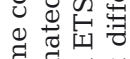

的曾苋

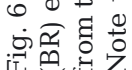


CR always increased after mixed additions (up to 51.5-fold) (Bonferroni post hoc test, p < 0.001; Table 2) and to a lesser extent after organic additions (up to 23.9-fold) in all the experiments except for Expt S1 (Bonferroni post hoc test, p < 0.05) (Fig. 6F).

The effects of the addition treatment, time, and experiment on $\mathrm{BB}, \mathrm{HNA} / \mathrm{BB}$ ratio, $\mathrm{BP}, \mathrm{BR}, \mathrm{BGE}$, and $\mathrm{CR}$ were all significant (RMANOVA, $p<0.001$ ). A significant interaction between the factors treatment and experiment was found for all variables (RMANOVA, $\mathrm{p}<0.001)$; that is, the effect of the addition treatment differed among experiments. Significant stimulations of $\mathrm{BB}, \mathrm{HNA} / \mathrm{BB}$ ratio, $\mathrm{BP}$, and $\mathrm{CR}$ were observed after organic and mixed additions, whereas BGE and BR significantly increased only after mixed additions (Bonferroni post hoc test, p < 0.05; Table 2).

\section{DISCUSSION}

Seasonality of nutrient inputs and irradiance levels in the study area (Nogueira et al. 1997), associated with hydrological and meteorological variability, allowed us to sample a wide range of microbial plankton communities in terms of both structure and functioning (Figs. $2 \& 3$ ).

Major differences in the response of phytoplankton and heterotrophic bacteria biomass and metabolisms to nutrient additions were found among experiments, suggesting that the processes that control autotrophic and heterotrophic microbial standing stocks and activity change both over seasonal and short spatial scales.

\section{Responses of phytoplankton}

Phytoplankton did not respond to any of the nutrient additions in Expt S3 (Fig. 5), where chl $a, \mathrm{PP}$, and $F_{\mathrm{v}} / F_{\mathrm{m}}$ exhibited very low values throughout the experiments. The lack of response observed in this experiment suggests that phytoplankton populations were likely in a senescent growth phase at the time of sampling. This is in agreement with the net heterotrophic microbial plankton metabolism and the very low PhytoB/BB ratio estimated (Fig. 3).

Previous studies in coastal zones have frequently shown increases in phytoplankton biomass and production rates after inorganic nutrient additions (Caron et al. 2000, Joint et al. 2002, Lignell et al. 2003). However, we found this response only in Expt S2, while in the rest of the experiments (Expts S1, R1, R2, and R3), phytoplankton growth increased only when inorganic and organic nutrients were jointly added (Fig. 5). The explanation for the general lack of response of phytoplankton to the in- organic nutrient treatment is not straightforward, and several mechanisms including both bottom-up and topdown control processes can be proposed.

Firstly, we can hypothesize that co-limitation by inorganic and organic nutrients could be related to the specific requirements for organic compounds of the phytoplankton species present. In this regard, mixotrophy and auxotrophy of coastal phytoplankton communities have been widely reported (Antia et al. 1991, Bronk et al. 2007, Burkholder et al. 2008). Release and uptake of amino acids tend to be closely linked so that ambient concentrations of dissolved free amino acids (DFAA) are usually very low and represent a small fraction of the measured DON (Berman \& Bronk 2003). However, Bronk et al. (2007) reported that the contribution of urea and DFAA to total measured $\mathrm{N}$ uptake by coastal phytoplankton might be as high as $80 \%$. The organic compounds potentially required for phytoplankton growth may have been supplied in the mixed treatment bottles by 2 non-exclusive pathways: by the organic addition itself or through the release of secondary metabolites derived from bacterial metabolism. The latter explanation would imply a trophic coupling between heterotrophic bacteria metabolism and PP. Bacterial activity has been previously proposed as a factor that can stimulate phytoplankton growth (Kurata 1986, Croft et al. 2005).

Secondly, the lack of response of phytoplankton in the inorganic treatment could be related to a time lag in the response of primary producers to nutrient additions or to top-down processes. Prefiltration $(200 \mu \mathrm{m}$ pore size mesh) of the samples could partially release ciliates and heterotrophic flagellates from predators, thus enhancing grazing pressure by microbial protists on phytoplankton. In these scenarios, only the extra nutrient input associated with remineralization by heterotrophic bacteria in the mixed treatment bottles would allow phytoplankton to sustain sufficiently high growth rates and give way to a bloom.

A previous microcosm experiment conducted with microplankton populations collected in the Western English Channel also failed to find a response by phytoplankton communities incubated for $7 \mathrm{~d}$ in inorganic nutrient-rich water and under constant environmental conditions (stability in the ambient light, temperature, and mixing conditions) (Fernández et al. 1992). Therefore, the lack of phytoplankton response to inorganic nutrient addition found in some of our experiments cannot be necessarily attributed to the relatively short incubation periods. On the other hand, large phytoplankton, which mostly dominated the phytoplankton community in our experiments, would not presumably be severely grazed in this $200 \mu \mathrm{m}$ prefiltered water.

In any case, the concentration of inorganic nutrients is already high in the inorganic treatment, making it 
therefore unlikely that remineralization had provided such an extra input as to make a difference. In addition, it has been shown that heterotrophic bacteria only significantly mineralize $\mathrm{N}$ from amino acids under conditions of extreme C limitation (Goldman \& Dennet 1991).

Few studies have attempted to determine the response of microbial plankton communities to inorganic and organic inputs and most of them assessed the effect of organic C (Caron et al. 2000, Jacquet et al. 2002, Joint et al. 2002). These investigations did not find a positive response of phytoplankton to labile DOC and even reported that phytoplankton biomass and production decreased in the presence of excess labile DOC as a result of enhanced heterotrophic bacterial activity that reduced the amount of inorganic nutrients ( $\mathrm{P}$ and $\mathrm{N}$ ) available for phytoplankton (Joint et al. 2002). Davidson et al. (2007) found positive responses by phytoplankton populations after the addition of organic $\mathrm{N}$ alone or in conjunction with inorganic nutrients, which they attributed to the extra inorganic nutrient input as a result of remineralization processes by heterotrophic bacteria. This is in agreement with the results observed in the present study in 4 out of 5 experiments in which phytoplankton responded to the mixed but not to the inorganic additions. We conclude that phytoplankton growth requirements for organic additions may be relevant in this coastal area, and likely change over spatial and temporal scales.

\section{Responses of heterotrophic bacteria}

Parallel sharp decreases in ammonium, phosphate, and DOC concentrations during the first incubation day in the mixed treatment (Fig. 4) coincided with increases in BP rates (Fig. 6), indicating a high rate of nutrient consumption by heterotrophic bacteria. It has been shown that, over time scales of days, bacteria preferentially use inorganic sources of $\mathrm{N}$ and $\mathrm{P}$ to support growth (Zweifel et al. 1993). Furthermore, enhanced nutrient uptake by C-limited heterotrophic bacteria was observed when supplied with glucose (Thingstad et al. 2008). Also, bacteria have been shown to be more efficient than phytoplankton in the uptake of ammonium and phosphate (Joint et al. 2002).

Heterotrophic bacteria did not respond to inorganic nutrient additions alone in the study area (Bonferroni post hoc test, p > 0.05; Table 2), suggesting a broad limitation by organic $\mathrm{C}$. On the other hand, bacteria could be co-limited by inorganic and organic nutrients in the shelf (Expts S1 and S2), since they only responded to the mixed treatments (Bonferroni post hoc test, $\mathrm{p}<0.001$ ) and to a lesser extent in Expts S3 and R2, where although both BB and BP increased after organic nutrient additions, further increases were registered after mixed additions (Bonferroni post hoc test, $\mathrm{p}<0.001$ ). This kind of response (secondary inorganic nutrient limitation) suggests that the additional inorganic nutrients supplied in the mixed treatment allowed bacteria to utilize more organic matter than when adding organic nutrients alone. Our results point to a large degree of temporal variability in the magnitude of inorganic nutrient availability in the studied area.

Considering that our organic addition includes $\mathrm{N}$ but not $\mathrm{P}$, co-limitation by organic and inorganic nutrients suggested in Expts S1 and S2 could be likely explained by $\mathrm{P}$ deficiency at the shelf station as inferred from the initial low phosphate concentrations (Table 1).

Limitation of heterotrophic bacteria biomass and activity in coastal areas by organic C (Jacquet et al. 2002, Joint et al. 2002, Davidson et al. 2007) and inorganic nutrients (Caron et al. 2000, Lignell et al. 2003) has been previously reported. Inorganic nutrient limitation has been suggested to prevent bacteria from utilizing organic $\mathrm{C}$, thus resulting in DOC accumulation in the upper water column (Rivkin \& Anderson 1997, Thingstad et al. 1997, Tanaka et al. 2009). This is in agreement with our experiments, where P deficiency could have prevented the bacterial utilization of the labile DOC and DON added in Expts S1 and S2.

Limitation of bacterial activity by organic $\mathrm{C}$ can be somewhat unexpected for a productive coastal area where both continental inputs (Aminot et al. 1990, Zweifel et al. 1995, Álvarez-Salgado et al. 2006) and high production rates associated with phytoplankton blooms contribute to DOM production and accumulation. However, it is well known that photosynthetically derived organic matter may not always be directly available to heterotrophic bacteria (Joint et al. 2002), and that most terrestrial materials, such as humic substances, are essentially refractory (Cauwet 2002). On the other hand, long-term (approximately 2 mo) DOM bacterial degradation experiments in the Ría de Vigo showed that $17 \%$ of DOC was labile or semilabile (Lønborg et al. 2010). A possible explanation for the apparent general organic $\mathrm{C}$ limitation of bacteria in our experiments could be enhanced predation pressure by microbial protists on bacteria due to the prefiltration procedure (Caron et al. 2000). A strong grazing pressure on bacteria could have masked the response of bacteria in the inorganic treatment. Only the extra organic $\mathrm{C}$ input in the organic treatment bottles allowed heterotrophic bacteria to sustain high enough growth rates to overcome predation losses.

A general organic C limitation of BGE may explain the increases in BGE registered after organic and mixed additions but not when adding inorganic ( $\mathrm{N}$ and P) nutrients alone (Fig. 6E). This is in agreement with 
previous manipulation experiments that showed little or no effect of inorganic nutrient additions on BGE in coastal areas (Jørgensen et al. 1993, Zweifel et al. 1993, Daneri et al. 1994). A recent field study by Apple \& del Giorgio (2007) also suggested that BGE is mainly controlled by the DOC pool. The lack of BGE response in the organic treatment observed in Expts S1 and S2 (Fig. 6E) could be related to the aforementioned colimitation by inorganic $\mathrm{P}$ and organic nutrients. This co-limitation of BGE by inorganic and organic nutrients has been widely documented (del Giorgio \& Cole 2000 and references therein) and several studies have reported evidence that $\mathrm{P}$ may control BGE in marine systems (Zweifel et al. 1993, Pomeroy et al. 1995).

\section{Metabolic balance of microbial plankton communities}

When organic $\mathrm{C}$ is available, heterotrophic bacteria may utilize inorganic nutrients to satisfy their demands, thus possibly outcompeting phytoplankton. This implies a decrease in the photosynthesis-to-respiration ratio when organic nutrients enter the pelagic ecosystem. In contrast, when inorganic nutrients are added, phytoplankton may utilize inorganic nutrients, and an increase in the photosynthesis-to-respiration ratio after inorganic inputs could be expected.

Changes in the $\mathrm{PP} / \mathrm{CR}$ ratio as a consequence of the nutrient additions (expressed as the PP/CR ratios in the addition treatments compared to those in the control: $\mathrm{PP} / \mathrm{CR}_{\mathrm{RR}}$ Inorganic, $\mathrm{PP} / \mathrm{CR}_{\mathrm{RR}}$ OOrganic, and $\mathrm{PP} / \mathrm{CR}_{\mathrm{RR}}$ Mixed) have been plotted against the initial $\mathrm{PP} / \mathrm{CR}$ ratio (PP/CR_i) (Fig. 7). These PP/CR $\mathrm{RR}_{\text {can }}$ be interpreted as relative short-term tendencies towards autotrophy $\left(\mathrm{PP} / \mathrm{CR}_{\mathrm{RR}}>1\right)$ or towards heterotrophy $\left(\mathrm{PP} / \mathrm{CR}_{\mathrm{RR}}<1\right)$ of the addition treatments compared to the control. The dashed line is the regression line $\mathrm{PP} / \mathrm{CR}_{\mathrm{RR}}=1 /(\mathrm{PP} / \mathrm{CR} \mathrm{i})$, and represents, for any given $\mathrm{PP} / \mathrm{CR} \mathrm{i}$, the $\mathrm{PP} / \mathrm{CR}_{\mathrm{RR}}$ that would result in a net metabolic balance equal to 1 . Therefore, points above the line would be net autotrophic and points below the line net heterotrophic.

The magnitude of response of the $\mathrm{PP} / \mathrm{CR}$ ratio in the organic and mixed addition treatments compared to the control (PP/CR $\mathrm{RR}_{\mathrm{R}}$ Organic and PP/CR $\mathrm{RR}_{-}$Mixed) significantly increased as the initial relative importance of autrotrophs in the microbial community was higher (Fig. 7B,C). Thus, after organic and mixed additions, changes in the metabolic balance of the plankton community were predictable: the lower the PP/CR_i, the stronger the tendency to heterotrophy after the additions (PP/CR $\left.\mathrm{RR}_{\mathrm{R}}<1\right)$ (Fig. 7B,C). In contrast, after inorganic additions, $\mathrm{PP} / \mathrm{CR}_{\mathrm{RR}}$ was not correlated with PP/CR_i, and microbial communities became net autotrophic in all cases (except for Expt S3, in which no
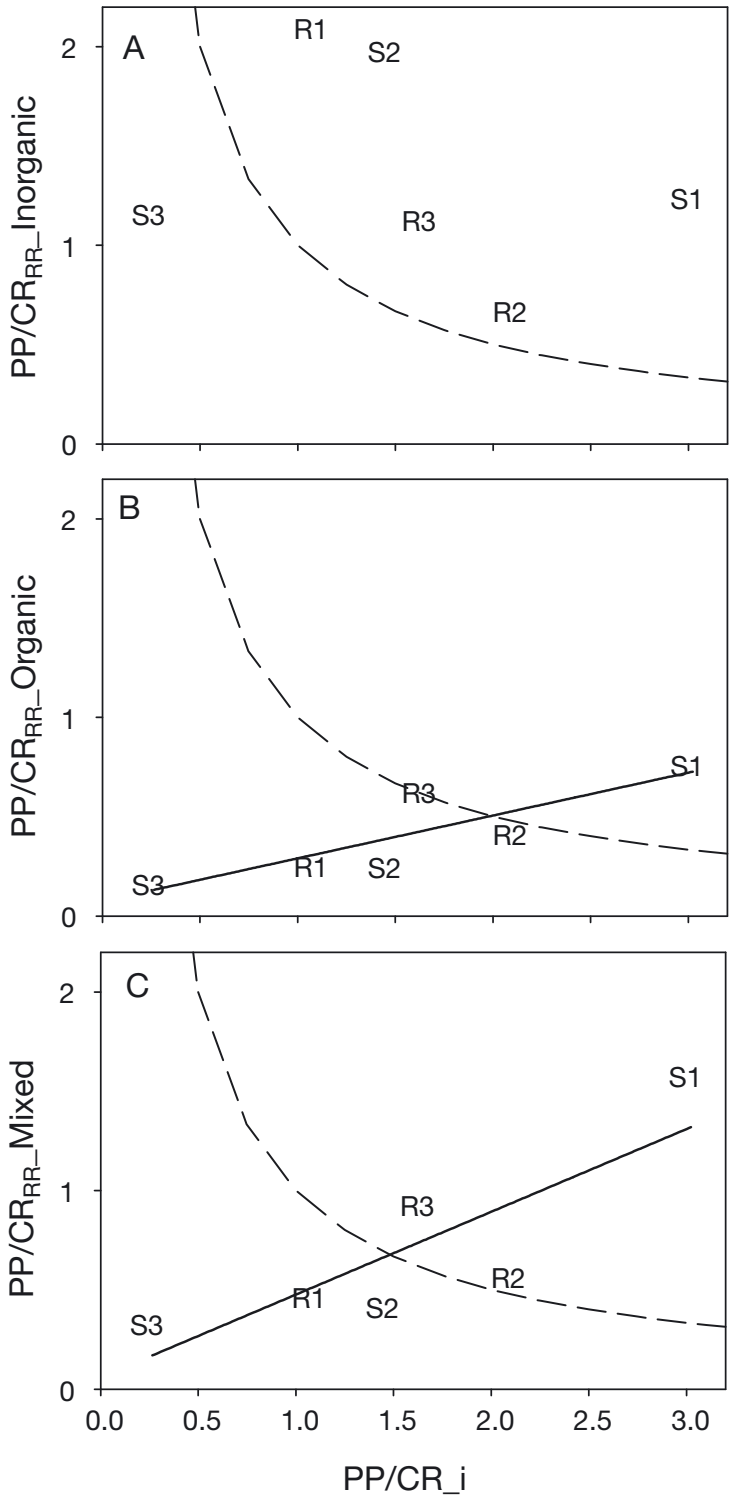

Fig. 7. Initial primary production to community respiration ratio (PP/CR_i) versus primary production to community respiration response ratio $\left(\mathrm{PP} / \mathrm{CR}_{\mathrm{RR}}\right)$ for $(\mathrm{A})$ inorganic additions; (B) organic additions $\left(y=0.216 x+0.075, r^{2}=0.74, p<0.05\right)$; and $(\mathrm{C})$ mixed additions $\left(y=0.417 x+0.059, \mathrm{r}^{2}=0.70, \mathrm{p}=0.05\right)$ for the 6 experiments ( $\mathrm{S} 1$ to $\mathrm{S} 3$ and $\mathrm{R} 1$ to $\mathrm{R} 3$ ). The regression line $y=1 / x$ (dashed line) corresponds to PP/CR $=1$. Points above the line are net autotrophic and points below the line are net heterotrophic

phytoplankton response was registered). Therefore, although changes in the microbial metabolic balance after organic additions (mainly driven by changes in $\mathrm{CR})$ depend on the initial microbial community metabolism, the changes after inorganic additions (mainly driven by unpredictable changes in PP) do not depend on the initial community metabolism.

It is noteworthy that, when organic and inorganic nutrients were jointly added, not only did heterotro- 
phic bacteria benefit but phytoplankton biomass and activity also increased. Therefore, the expected imbalance between autotrophic and heterotrophic processes in response to mixed additions may be reduced.

To what extent the tendency to heterotrophy can be attenuated seemed to be dependent on the initial structure of the microbial community. The tendency to heterotrophy of the microbial plankton communities was stronger in the organic than in the mixed treatment bottles (PP/CR $\mathrm{RR}_{2}$ Organic $<\mathrm{PP} / \mathrm{CR}_{\mathrm{RR}}$ Mixed) in all the experiments, and in one of them (Expt R2) the net metabolism of the microbial community even changed from net heterotrophic after the organic treatment (Expt R2 below the dashed line representing PP/ $\mathrm{CR}=1$ ) to net autotrophic after the mixed treatment (Expt R2 above the dashed line) (Fig. 7B,C).Therefore, the fact that phytoplankton also benefit from mixed additions may partially compensate the tendency towards heterotrophy in marine planktonic systems receiving increasing amounts of organic matter. This is of interest in the context of predicting possible shifts in the metabolic balance of microbial communities in coastal areas that are subjected to increasingly higher anthropogenic inputs. Future studies should consider the effects of both inorganic and organic nutrients, taking into account that variations in the initial composition of the communities and complex trophic interactions make it difficult to observe universal responses of microbial communities to coastal eutrophication.

Acknowledgements. We thank all the people involved in the project AddEx who helped with the preparation and sampling of the experiments. We also thank C. Carreira, L. DíazPérez, A. Fernández, E. García, M. Huete, M. Pérez, A. Franco, C. Sobrino, and V. Vieitez for their help during the experimental work. We thank Estación de Ciencias Mariñas de Toralla (ECIMAT) for the technical support during the experiments as well as the crew of the RV 'Mytilus' for their help during the work at sea. Access to vessel time was provided by the RAFTING project (CTM2007-61983/MAR). This research was supported by the Xunta de Galicia through projects AddEx (grant PGIDIT06PXIB312222PR) and IMAN (grant 07MMA002402PR). S.M.-G. was funded by an FPU MEC fellowship. E.T. was funded by a Juan de la Cierva and a Ramón y Cajal-MEC contract. C.L. was funded by a fellowship from the Early Stage Training site ECOSUMMER (MEST-CT-2004-0205019) and the Carlsberg Foundation.

\section{LITERATURE CITED}

Álvarez-Salgado XA, Miller AEJ (1998) Simultaneous determination of dissolved organic carbon and total dissolved nitrogen in seawater by high temperature catalytic oxidation: conditions for precise shipboard measurements. Mar Chem 62:325-333

Álvarez-Salgado XA, Rosón G, Perez FF, Figueiras FG, Pazos $Y$ (1996) Nitrogen cycling in an estuarine upwelling system, the Ria de Arousa (NW Spain). I. Short-time-scale patterns of hydrodynamic and biogeochemical circulation. Mar Ecol Prog Ser 135:259-273
Álvarez-Salgado XA, Beloso S, Joint I, Nogueira E and others (2002) New production of the NW Iberian shelf during the upwelling season over the period 1982-1999. Deep-Sea Res I 49:1725-1739

Álvarez-Salgado XA, Nieto-Cid M, Gago J, Brea S, Castro CG, Doval MD, Pérez FF (2006) Stoichiometry of the degradation of dissolved and particulate biogenic organic matter in the NW Iberian upwelling. J Geophys Res 111: C07017 doi:10.1029/2004JC002473

Aminot A, El-Sayed MA, Kerouel R (1990) Fate of natural and anthropogenic dissolved organic carbon in the macrotidal Elorn estuary (France). Mar Chem 29:255-275

Antia NJ, Harrison PJ, Oliveira L (1991) The role of dissolved organic nitrogen in phytoplankton nutrition, cell biology and ecology. Phycologia 30:1-89

Apple JK, del Giorgio PA (2007) Organic substrate quality as the link between bacterioplankton carbon demand and growth efficiency in a temperate salt-marsh estuary. ISME J 1:729-742

Azam F, Fenchel T, Field JG, Gray JS, Meyer-Rail LA, Thingstad F (1983) The ecological role of water-column microbes in the sea. Mar Ecol Prog Ser 10:257-263

Benner R (2002) Chemical composition and reactivity. In: Hansell DA, Carlson CA (eds) Biogeochemistry of dissolved organic matter. Academic Press, San Diego, CA, p 153-231

> Berman T, Bronk DA (2003) Dissolved organic nitrogen: a dynamic participant in aquatic ecosystems. Aquat Microb Ecol 31:279-305

Bronk DA (2002) Dynamics of DON. In: Hansell DA, Carlson CA (eds) Biogeochemistry of dissolved organic matter. Academic Press, San Diego, CA, p 153-231

Bronk DA, See JH, Bradley P, Killberg L (2007) DON as a source of bioavailable nitrogen for phytoplankton. Biogeosciences 4:283-296

> Burkholder JM, Glibert PM, Skelton HM (2008) Mixotrophy, a major mode of nutrition for harmful algal species in eutrophic waters. Harmful Algae 8:77-93

> Calvo-Díaz A, Morán XAG (2006) Seasonal dynamics of picoplankton in shelf waters of the southern Bay of Biscay. Aquat Microb Ecol 42:159-174

Calvo-Díaz A, Morán XAG (2009) Empirical leucine-tocarbon conversion factors for estimating heterotrophic bacterial production: seasonality and predictability in a temperate coastal ecosystem. Appl Environ Microbiol 75: 3216-3221

Caron DA, Lim EL, Sanders RW, Dennett MR, Berninger UG (2000) Responses of bacterioplankton and phytoplankton to organic carbon and inorganic nutrient additions in contrasting oceanic ecosystems. Aquat Microb Ecol 22: $175-184$

Cauwet G (2002) DOM in the coastal zone. In: Hansell DA, Carlson CA (ed) Biogeochemistry of marine dissolved organic matter. Academic Press, San Diego, CA, p 579-609

> Cermeño P, Marañón E, Pérez V, Serret P, Fernández E, Castro CG (2006) Phytoplankton size structure and primary production in a highly dynamic coastal ecosystem (Ría de Vigo, NW Spain): seasonal and short-time scale variability. Estuar Coast Shelf Sci 67:251-266

> Cloern JE (2001) Our evolving conceptual model of the coastal eutrophication problem. Mar Ecol Prog Ser 210: 223-253

> Coble PG (1996) Characterization of marine and terrestrial DOM in seawater using excitation-emission matrix spectroscopy. Mar Chem 51:325-346

Croft MT, Lawrence AD, Raux-Deery E, Warren MJ, Smith 
AG (2005) Algae acquire vitamin B12 through a symbiotic relationship with bacteria. Nature 438:90-93

Daneri G, Riemann B, Williams PJleB (1994) In situ bacterial production and growth yield measured by thymidine, leucine and fractionated dark oxygen uptake. J Plankton Res 16:105-113

Davidson K, Gilpin LC, Hart MC, Foilland E and others (2007) The influence of the balance of inorganic and organic nitrogen on the trophic dynamics of microbial food webs. Limnol Oceanogr 52:2147-2163

del Giorgio PA, Cole JJ (2000) Bacterial energetics and growth efficiency. In: Kirchman DL (ed) Microbial ecology of the oceans, 1st edn. Wiley-Liss, New York, NY, p 289-326

$>$ Duce RA, LaRoche J, Altieri K, Arrigo KR and others (2008) Impacts of atmospheric anthropogenic nitrogen on the open ocean. Science 320:893-897

Estévez P (2007) Determinación de la producción primaria planctónica mediante fluorometría de alta tasa de repetición (fast repetition rate fluorometry). Validación de modelos empíricos predictivos. $\mathrm{PhD}$ dissertation, Universidad de Vigo

Falkowski PG, Barber TR, Smetacek V (1998) Biogeochemical controls and feedbacks on ocean primary production. Science 281:200-206

Fernández E, Serret P, de Madariaga I, Harbour DS, Davies A (1992) Photosynthetic carbon metabolism and biochemical composition of spring phytoplankton assemblages enclosed in microcosms: the diatom-Phaeocystis sp. succession. Mar Ecol Prog Ser 90:89-102

Galloway JN, Cowling EB (2002) Reactive nitrogen and the world: 200 years of change. Ambio 3:64-71

> Galloway JN, Dentener FJ, Capone DG, Boyer EW and others (2004) Nitrogen cycles: past, present, and future. Biogeochemistry 70:153-226

Goldman JC, Dennet MR (1991) Ammonium regeneration and carbon utilization by marine bacteria grown on mixed substrates. Mar Biol 109:369-379

Gruber N, Galloway JN (2008) An Earth-system perspective of the global nitrogen cycle. Nature 451:293-296

Hansen HP, Grasshoff K (1983) Automated chemical analysis. In: Grasshoff K, Ehrhardt M, Kermling K (eds) Methods of seawater analysis, 2nd edn. Verlag Chemie, Weinheim, p 347-395

- Howarth R, Marino R (2006) Nitrogen as the limiting nutrient for eutrophication in coastal marine ecosystems: Evolving views over three decades. Limnol Oceanogr 51:364-376

> Jacobson MC, Hansson HC, Noone KJ, Charlson RJ (2000) Organic atmospheric aerosols: review and state of the science. Rev Geophys 38:267-294

Jacquet S, Havskum H, Thingstad TF, Vaulot D (2002) Effects of inorganic and organic nutrient addition on a coastal microbial community (Isefjord, Denmark). Mar Ecol Prog Ser 228:3-14

> Joint I, Henriksen P, Fonnes GA, Bourne D, Thingstad TF, Riemann B (2002) Competition for inorganic nutrients between phytoplankton and bacterioplankton in nutrient manipulated mesocosms. Aquat Microb Ecol 29:145-159

Jørgensen NOG, Kroer N, Coffin RB, Hoch MP (1993) Dissolved free amino acids, combined amino acids, and DNA sources of carbon and nitrogen to marine bacteria. Mar Ecol Prog Ser 98:135-148

Jurado E, Dachs J, Duarte CM, Simó R (2008) Atmospheric deposition of organic and black carbon to the global oceans. Atmos Environ 42:7931-7939

Karl DM, Björkman KM (2002) Dynamics of DOP. In: Hansell DA, Carlson CA (eds) Biogeochemistry of dissolved or- ganic matter. Academic Press, San Diego, CA, p 250-348

- Kirchman DL (1994) The uptake of inorganic nutrients by heterotrophic bacteria. Microb Ecol 28:255-271

> Kirchman D, Knees E, Hodson R (1985) Leucine incorporation and its potential as a measure of protein synthesis by bacteria in natural aquatic systems. Appl Environ Microbiol 49:599-607

Kurata A (1986) Blooms of Uroglena americana in relation to concentrations of B group vitamins. In: Kristiansen J, Andersen RA (eds) Chrysophytes: aspects and problems. Cambridge University Press, Cambridge, p 185-196

Lignell R, Seppälä J, Kuuppo P, Tamminen T, Andersen T, Gismervik I (2003) Beyond bulk properties: responses of coastal summer plankton communities to nutrient enrichment in the northern Baltic Sea. Limnol Oceanogr 48: 189-209

Lønborg C, Álvarez-Salgado XA, Martínez-García S, Miller A, Teira E (2010) Stoichiometry of dissolved organic matter and the kinetics of its microbial degradation in a coastal upwelling system. Aquat Microb Ecol 58:117-126

> Lund JWG, Kipling C, Le Cren ED (1958) The inverted microscope method of estimating algal numbers and the statistical basis of estimations by counting. Hydrobiologia 11: $143-170$

Marañón E, Holligan PM, Barciela R, González N, Mouriño B, Pazó MJ, Varela M (2001) Patterns of phytoplankton size structure and productivity in contrasting open-ocean environments. Mar Ecol Prog Ser 216:43-56

> Marañón E, Cermeño P, Fernández E, Rodríguez J, Zabala L (2004) Significance and mechanisms of photosynthetic production of dissolved organic carbon in a coastal eutrophic ecosystem. Limnol Oceanogr 49:1652-1666

Martínez-García S, Fernández E, Aranguren-Gassis M, Teira $\mathrm{E}$ (2009) In vivo electron transport system activity: a method to estimate respiration in marine microbial planktonic communities. Limnol Oceanogr Methods 7:459-469

- Matthews D (2006) The water cycle freshens up. Nature 439: 793-794

> Menden-Deuer S, Lessard EJ (2000) Carbon to volume relationships for dinoflagellates, diatoms, and other protist plankton. Limnol Oceanogr 45:569-579

Meybeck M (1993) C, N, P and S in rivers: from sources to global inputs. In: Wollast R, Mackenzie FT, Chou L (eds) Interactions of $\mathrm{C}, \mathrm{N}, \mathrm{P}$ and $\mathrm{S}$. Biogeochemical cycles and global change. Springer-Verlag, Berlin, p 163-194

> Nieto-Cid M, Álvarez-Salgado XA, Pérez FF (2006) Microbial and photochemical reactivity of fluorescent dissolved organic matter in a coastal upwelling system. Limnol Oceanogr 51:1391-1400

Nixon SW (1995) Coastal marine eutrophication: a definition, social causes and future concerns. Ophelia 41:199-219

Nixon SW, Pilson MEQ (1983) Nitrogen in estuarine and coastal marine ecosystems. In: Carpenter EJ, Capone DG (eds) Nitrogen in the marine environment. Academic Press, New York, NY, p 565-648

- Nogueira E, Pérez FF, Ríos AF (1997) Seasonal patterns and long-term trends in an estuarine ecosystem (Ría de Vigo, NW Spain). Estuar Coast Shelf Sci 44:285-300

Norland S (1993) The relationship between biomass and volume of bacteria. In: Kemp PF, Sherr BF, Sherr EB, Cole JJ (eds) Handboook of methods in aquatic microbial ecology. Lewis Publishers, Boca Raton, FL, p 303-307

Olenina I, Hajdu S, Edler L, Andersson A and others (2006) Biovolumes and size-classes of phytoplankton in the Baltic Sea. HELCOM Baltic Sea Environment Proceedings 106. Helsinki Commission, Baltic Marine Environment Protection, Helsinki 
Oviatt C, Doering P, Nowicki B, Reed L, Cole J, Frithsen J (1995) An ecosystem level experiment on nutrient limitation in temperate coastal marine environments. Mar Ecol Prog Ser 116:171-179

Paerl HW, Dennis LR, Whitall DL (2002) Atmospheric deposition of nitrogen: implications for nutrient over-enrichment of coastal waters. Estuaries 25(4b):677-693

Peierls BL, Paerl HW (1997) Bioavailability of atmospheric organic nitrogen deposition to coastal phytoplankton. Limnol Oceanogr 42:1819-1823

Pomeroy LR, Sheldon JE, Sheldon WM, Peters F (1995) Limits to growth and respiration of bacterioplankton in the Gulf of Mexico. Mar Ecol Prog Ser 117:259-268

Rivkin RB, Anderson MR (1997) Inorganic nutrient limitation of oceanic bacterioplankton. Limnol Oceanogr 42:730-740

Robinson C (2008) Heterotrophic bacterial respiration. In: Kirchman DL (ed) Microbial ecology of the oceans, 2nd edn. Wiley-Liss, New York, NY, p 299-336

Rodriguez L, Macías F (2006) Eutrophication trends in forest soils in Galicia (NW Spain) caused by the atmospheric deposition of nitrogen compounds. Chemosphere 63: 1598-1609

Scheiner SM, Gurevitch J (1993) Design and analysis of ecological experiments. Chapman \& Hall, London

Seitzinger SP, Sanders RW (1999) Atmospheric inputs of dissolved organic nitrogen stimulate estuarine bacteria and phytoplankton. Limnol Oceanogr 44:721-730

Smith DC, Azam F (1992) A simple, economical method for measuring bacterial protein synthesis rates in seawater using ${ }^{3} \mathrm{H}$-leucine. Mar Microb Food Webs 6:107-114

Tanaka T, Thingstad TF, Gasol JM, Cardelús C and others (2009) Determining the availability of phosphate and glucose for bacteria in P-limited mesocosms of NW Mediterranean surface waters. Aquat Microb Ecol 56:81-91

Thingstad TF, Hagström A, Rassoulzadegan F (1997) Accu-

Editorial responsibility: Graham Savidge,

Portaferry, UK mulation of degradable DOC in surface waters: Is it caused by a malfunctioning microbial loop? Limnol Oceanogr 42:398-404

> Thingstad TF, Havskum H, Kaas H, Nielsen TG, Riemann B, Le Févre D, Williams PJleB (1999) Bacteria-protist interactions and organic matter degradation under P-limited conditions: analysis of an enclosure experiment using a simple model. Limnol Oceanogr 44:62-79

Thingstad TF, Bellerby RGJ, Bratbak G, Børsheim KY and others (2008) Counterintuitive carbon-to-nutrient coupling in an Arctic pelagic ecosystem. Nature 455:387-391

Vázquez A, Costoya M, Peña RM, García S, Herrero C (2003) A rainwater quality monitoring network: a preliminary study of the composition of rainwater in Galicia (NW Spain). Chemosphere 51:375-386

> Vitousek PM, Mooney HA, Lubchenco J, Melillo JM (1997) Human domination of Earth's ecosystems. Science 277: 494-499

Welschmeyer NA (1994) Fluorometric analysis of chlorophyll $a$ in the presence of chlorophyll $b$ and pheopigments. Limnol Oceanogr 39:1985-1992

Williams PJleB, del Giorgio PA (2005) Respiration in aquatic ecosystems: history and background. In: del Giorgio PA, Williams PJleB (eds) Respiration in aquatic ecosystems. Oxford University Press, London, p 1-18

Worden AZ, Nolan JK, Palenik B (2004) Assessing the dynamics and ecology of marine picophytoplankton: the importance of the eukaryotic component. Limnol Oceanogr 49: 168-179

Z Zweifel UL, Norrman B, Hagström A (1993) Consumption of dissolved organic carbon by marine bacteria and demand for inorganic nutrients. Mar Ecol Prog Ser 101:23-32

Zweifel UL, Norrman B, Hagström A (1995) Dynamics of dissolved organic carbon in a coastal ecosystem. Limnol Oceanogr 40:299-305

Submitted: May 6, 2010; Accepted: August 20, 2010

Proofs received from author(s): September 28, 2010 